\title{
Probabilistic Liquefaction Potential of Kathmandu Soil Based On Standard Penetration Tests
}

Mandip Subedi ( $\square$ mandip.subedi@gmail.com )

Tribhuvan University Institute of Engineering Department of Civil Engineering

Indra Prasad Acharya

Tribhuvan University Institute of Engineering

Research

Keywords: Kathmandu Valley, Soil Liquefaction, Probability Index, Hazard Mapping, SPT

Posted Date: July 13th, 2021

DOI: https://doi.org/10.21203/rs.3.rs-685901/v1

License: (c) (1) This work is licensed under a Creative Commons Attribution 4.0 International License.

Read Full License 


\title{
Probabilistic liquefaction potential of Kathmandu soil based on standard penetration tests
}

\author{
Mandip Subedi ${ }^{1 *}$ and Indra Prasad Acharya ${ }^{1}$ \\ ${ }^{1}$ Department of Civil Engineering, Institute of Engineering, Pulchowk Campus, Tribhuvan \\ University, Nepal \\ *Corresponding author: mandip.subedi@ gmail.com
}

\begin{abstract}
Despite being a liquefaction susceptible zone, Kathmandu Valley soil in Nepal has limited studies on liquefaction potential and most of them are based on the deterministic approach. Although this method is widely used, it ignores the uncertainties of seismic parameters such as peak ground acceleration, $a_{\mathrm{max}}$, and earthquake magnitude, $M_{\mathrm{w}}$ as well as the inherent variabilities of soil layers, in-situ testing procedures, and geotechnical properties. On the other hand, the probabilistic approach helps assess the liquefaction potential by considering all these uncertainties. In this study, we assess the liquefaction hazard in the Kathmandu Valley using the first-order second-moment (FOSM) method as a probabilistic approach for liquefaction hazard assessment. The assessment is done for three likely-to-recur scenario earthquakes utilizing the geotechnical data of 1510 boreholes. The soils are characterized geotechnically to further assess susceptibility criteria of liquefaction in the valley. The assessment reveals that the central part of the valley is more vulnerable to liquefaction than other parts and the liquefaction probability increases with increasing depth up to $9 \mathrm{~m}$, after which has geared down the value. Moreover, a relationship between the probability of liquefaction $\left(P_{\mathrm{L}}\right)$ and the factor of safety (FS) against liquefaction is established. The hazard maps prepared for different earthquake scenarios can be useful for future infrastructure planning in Kathmandu Valley.
\end{abstract}

\section{KEYWORDS}

Kathmandu Valley; Soil Liquefaction; Probability Index; Hazard Mapping; SPT 


\section{INTRODUCTION}

Liquefaction of soil is a common earthquake consequence and often results in massive ground failure and structural damage. It occurs as a result of loss of strength especially by saturated granular soils due to abrupt rise in excess porewater pressure and its equivalence to total stress during strong earthquake shakings (Choobbasti et al., 2015; Seed \& Idriss, 1971). For the soil liquefaction to occur, an earthquake must produce a certain degree of lateral force with an appropriate magnitude, duration, and peak ground acceleration (PGA) (Seed et al., 2001).

Soil liquefaction emerged as a great geotechnical challenge back in 1964 when the extent of damage during the Niigata Earthquake $\left(M_{\mathrm{w}} 7.5\right)$ in Japan and the Alaska Earthquake $\left(M_{\mathrm{w}} 9.2\right)$ in the United States raised serious questions. More recently, soil liquefaction-led ground failure and structural damage were also observed during the Kashmir Earthquake in $2010\left(M_{\mathrm{w}} 7.6\right.$, India and Pakistan), Chile Earthquake in 2010 ( $\left.M_{\mathrm{w}} 8.8\right)$, Emilia-Romagna Earthquake in 2012 ( $M_{\mathrm{w}} 5.9$, Italy), Japan Earthquake, Japan, in 2012 ( $\left.M_{\mathrm{w}} 7.3\right)$, and Sulawesi Earthquake in 2018 ( $M_{\mathrm{w}} 7.5$, Indonesia). In Nepal too, the recorded historical earthquakes of 1408, $1833\left(M_{\mathrm{L}} 7.7\right), 1934\left(M_{\mathrm{w}} 8.1\right), 1988$ $\left(M_{\mathrm{w}} 6.8\right)$, and the recent 2015 earthquake $\left(M_{\mathrm{w}} 7.8\right)$ caused liquefaction damages in different parts of the country including the capital city area of the Kathmandu Valley (Gautam et al., 2017; Sharma et al., 2019).

Spread over an area of about $665 \mathrm{~km}^{2}$ and with an estimated resident population of 5 million, the Kathmandu Valley has a core urban population density of 13,225 per km² (KMC, 2011). As a typical bowl-shaped ancient lake deposit (see Figure 1), the valley ground is especially prone to amplified shakings during earthquakes. This has been evidenced by many historical earthquakes in the Nepal Himalaya, such as in 1934, 1960, 1988 and 2015 (Gautam et al., 2017). The valley ground with a maximum estimated depth of nearly 650 meters is characterized by the lacustrine and fluvial deposits (Sakai, 2001). The deposits mostly consist of a mixture or alternating layers of clay, silt, sand, and gravel (UNDP/HMG/UNCHS, 1994; Piya, 2004; Sharma et al., 2016; Subedi et al., 2018) with comparatively shallow groundwater table (Pathak et al., 2009; Shrestha et al., 2016). At present, the Kathmandu Valley lies in a category of seismically active area at risk of shaking with a PGA of $0.36 \mathrm{~g}$. 
Despite greater risk of earthquake damage, however, the whole valley area has seen a rapid rise in construction of residential buildings, public buildings, business complexes, road bridges and flyovers and so on in recent decades, mainly to overcome a greater demand of accommodating internal migration-led increased and still increasing population in the valley. As these construction and infrastructure development activities are expected to further increase in the days ahead, it is inevitable to investigate and examine the construction site ground conditions for the structural safety and stability against any seismic shaking as well as potential risk of soil liquefaction.

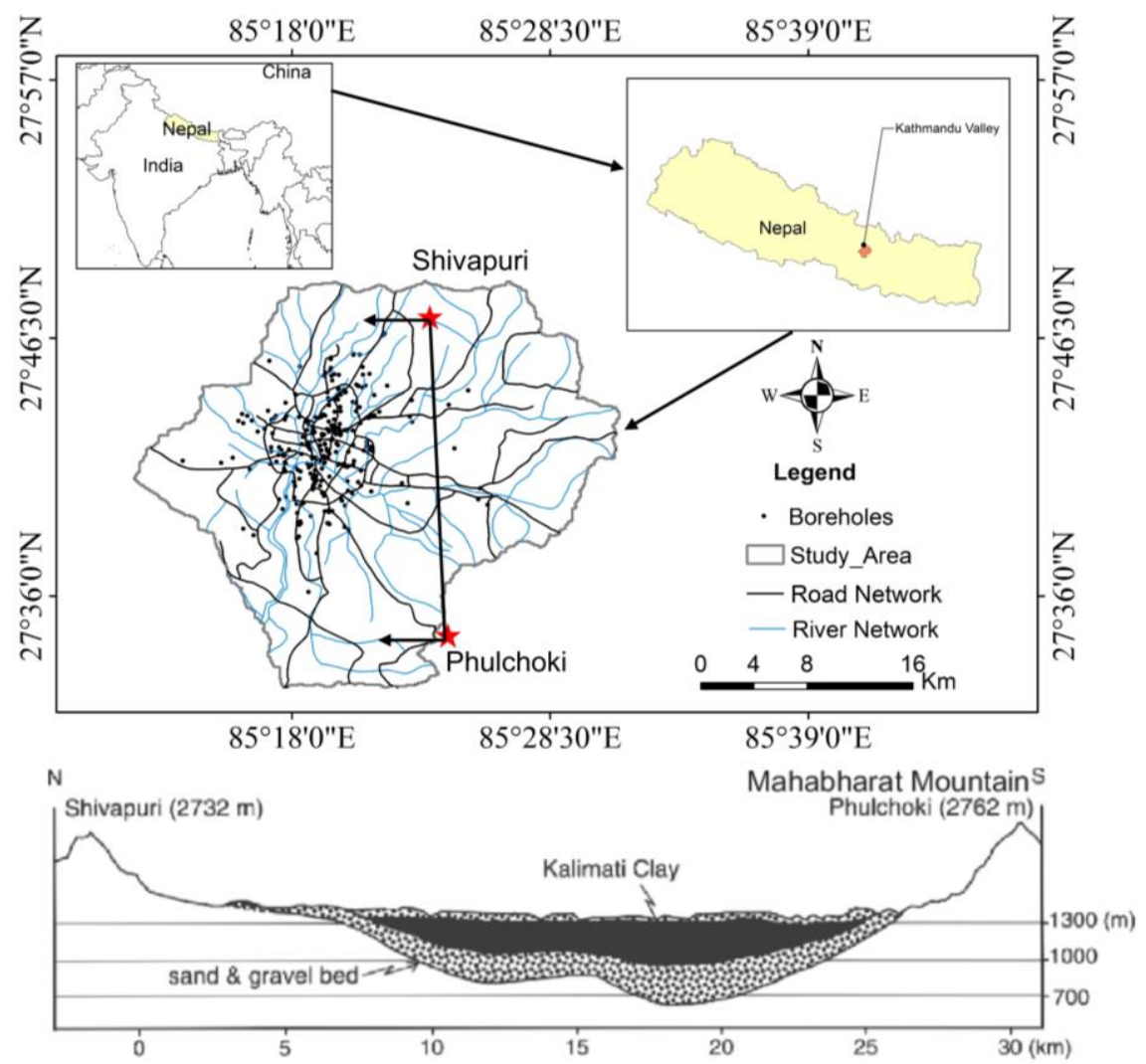

Figure 1. Map showing location of Kathmandu Valley along with major river and road networks, and boreholes. A schematic geological north-south cross-section of the valley (after Sakai et al. (2002)) is presented.

Liquefaction risk study in the Kathmandu Valley is still considered inadequate although we have a few locally available main reference materials prepared and proposed by UNDP (1994), JICA (2002), and Piya (2004). All these studies adopted deterministic approach to liquefaction potential analysis, and have presented unrepresentative and underestimated liquefaction susceptibility of the Kathmandu Valley soil (Gautam et al., 2017; Jha et al., 2020; K. C. et al., 2020; Sharma et al., 
2016, 2018, 2019). As some recent studies on earthquake risk in the Himalaya region have warned that an enormous strain buildup in the region is likely to produce an earthquake of $M_{\mathrm{w}} 8.5$ class in near future (Rajendran, 2021), we consider it necessary to reassess the liquefaction potential in the Kathmandu Valley more comprehensively through probabilistic approach.

Various methods are in practice and have been used for evaluating the soil liquefaction potential (e.g., Seed \& Idriss, 1971; Seed et al., 1983; Seed et al., 1985; Youd and Idriss, 2001; Idriss and Boulanger, 2010). Basically, it is evaluated using the factor of safety (FS), which is a ratio of cyclic resistance ratio (CRR) to the cyclic stress ratio (CSR). Although the deterministic approach, as mentioned above, is widely used as a simplified procedure to evaluate soil liquefaction potential, it ignores the uncertainties associated with the seismic parameters such as $a_{\max }$ (i.e., maximum acceleration or the peak ground acceleration) and $M_{\mathrm{w}}$ (i.e., the earthquake moment magnitude) as well as the with natural variability in the soil layers, geotechnical properties, and in situ testing procedures required to estimate CSR and CRR. Beginning late 1980s, a few probabilistic and statistical models have been proposed (e.g., Liao et al. (1988), Youd and Noble (1997), Liao and Lum (1998), Toprak et al. (1999), Juang et al. (2002), Cetin et al. (2002, 2004), Moss et al. (2006) and Idriss and Boulanger (2012) among many others). Boulanger and Idriss (2014) have proposed a probabilistic method based on case history data from cone penetration tests (CPT). Despite the availability of these encouraging methods, majority of the geotechnical engineers underestimate the utility of probabilistic liquefaction analysis techniques.

We have employed probabilistic approach in this study, which assists in evaluating the liquefaction potential by accounting for the uncertainties associated with various parameters and in elucidating the nature of the uncertainties associated with various factors. Hwang et al. (2004) and Jha and Suzuki (2009a) identified the approaches to evaluating liquefaction potential based on Standard Penetration Test (SPT) data while accounting for the uncertainties.

With the main objectives of using probabilistic method for evaluating the liquefaction potential in Kathmandu Valley soil, in this study we adopt the reliability approach in assessing soil liquefaction. Available borehole data as well as field investigation data for this particular study have been used for this purpose. We also conducted several sets of laboratory tests on selected soil 
samples. In addition, three scenario earthquakes have been considered in doing the probabilistic analyses: $M_{\mathrm{w}} 7.8$ (PGA $0.18 \mathrm{~g}$, the Gorkha Earthquake), $M_{\mathrm{w}} 8.0$ (0.30g PGA, based on the JICA (2002) study with $10 \%$ probability of exceedance in 50 years), and $M_{\mathrm{w}} 8.4$ (PGA $0.36 \mathrm{~g}$, suggested by Nepal Building Code (NBC, 2020)). We perform a reliability study using the first-order secondmoment (FOSM) method on all borehole sites considering the three scenario earthquakes and establish a connection between the factor of safety (FS) and probability of liquefaction $\left(P_{\mathrm{L}}\right)$. Then, liquefaction hazard maps are created in terms of $P_{\mathrm{L}}$ values using the built-in geostatistical analysis tool of ArcGIS.

\section{STUDY AREA}

\subsection{GEOGRAPHY AND GEOLOGY}

The Kathmandu Valley is at an average elevation of 1340 metres. Surrounded by mid-height mountains and drained by a river system called Bagmati, a bowl-shaped Kathmandu Valley has a more or less flat terrain except for a few gorges created by the river network. The main river system merge near the valley center and drain the valley watershed through Chovar gorge at the southern points of the valley (Figure 1). 


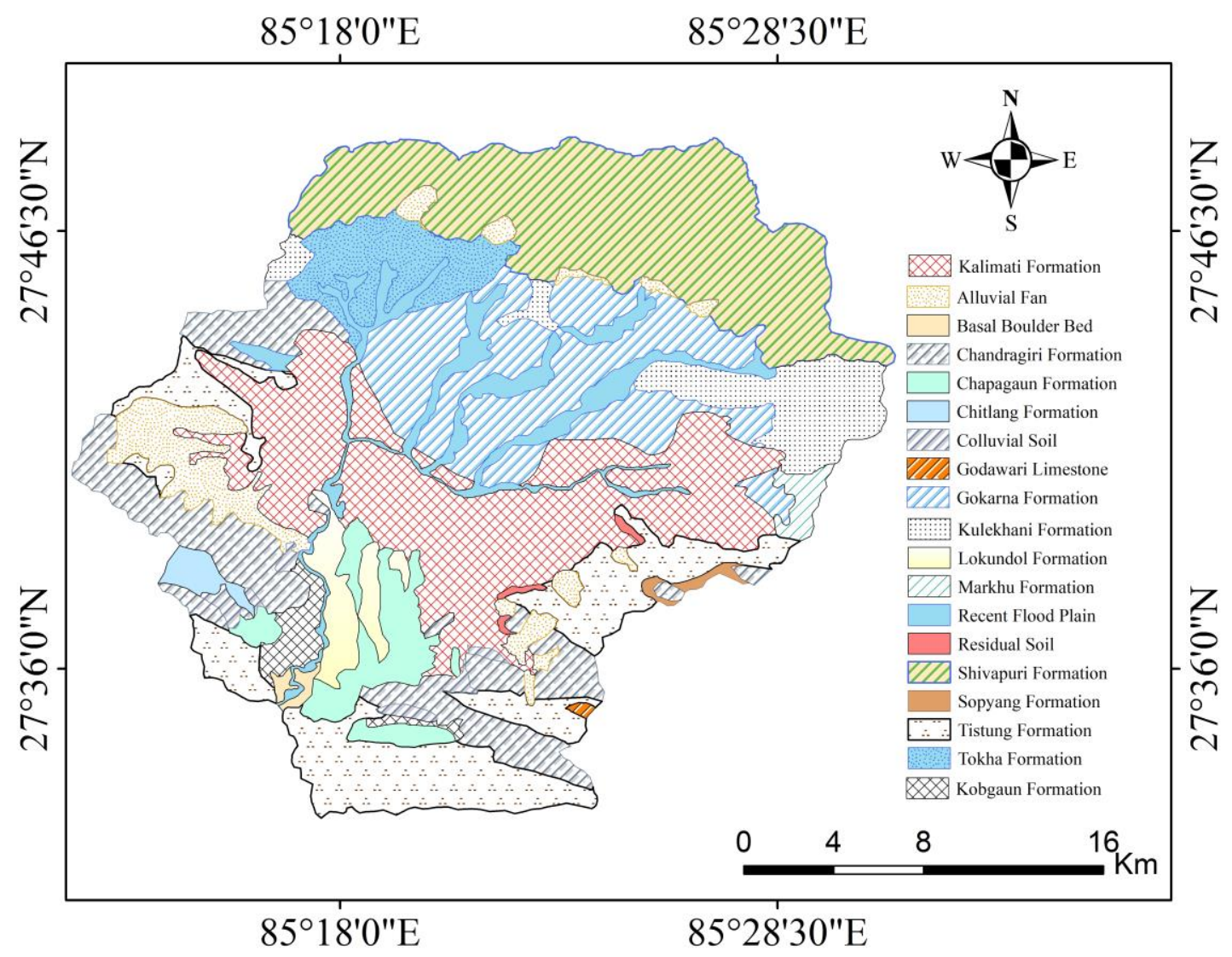

Figure 2. Geological formation map of Kathmandu Valley redrawn after Dhital (2015)

As a deep sediment-filled ancient lake, the surface geology of the Kathmandu Valley deposit is mainly characterized by the type of materials transported from the peripheral mountains (Paudyal et al., 2013). A typical geological map of the valley deposit is shown in Figure 2 (redrawn after Dhital (2015)). Sedimentary rocks in the valley basement are primarily covered by massive fluviallacustrine deposits of the Pliocene to the Pleistocene periods. The sediment deposits are mostly a mixture and alternate layers of clay, silt, sand, and gravel (UNDP/HMG/UNCHS, 1994; Piya, 2004; Mugnier et al., 2011; Sharma et al., 2016; Subedi et al., 2018) with relatively shallow groundwater table (Pathak et al., 2009; Shrestha et al., 2016). The material in the northern part of the valley is typical riverbed stratified deposits of clays, silts, sand, and gravels. Alluvial fan facies are evident in the valley south end that agglomerates of boulders and gravels with clayey and silty matrixes were derived from debris flows from the southern hill. Additionally, the middle part of the basin is mostly thick layers of organic mud and black clay material. All this makes it clear that relatively coarse material (i.e., coarse silt, sand, and fine gravel) deposited areas in the Kathmandu 
Valley are particularly prone to liquefaction (Okamura et al., 2015; Sharma et al., 2019; Subedi et al., 2013).

\subsection{SEISMICITY AND SEISMIC HAZARD}

Continental drift is the most accepted cause of frequent earthquakes in the South Asian Region including Nepal, Bangladesh, Pakistan and India (Jouanne et al., 2004). The Himalayan mountains are the consequences of this continental drift that occurs at the rates of 35-38 mm/year towards $\mathrm{N}$ $\mathrm{NE}$ of the Indian continent colliding with and subducting underneath the Eurasian plate (Holt et al., 2000; Jouanne et al., 2004). As a result of this, the Nepal Himalaya consists of four major tectonic zones separated by the South Tibetan Detachment System (STDS), the Main Central Thrust (MCT), the Main Boundary Thrust (MBT), and the Main Frontal Thrust (MFT) in north to south direction (Sapkota et al., 2013). Additionally, the region is home to a number of active local faults that also are potential hotspots of damaging earthquakes.

As also stated in the previous section, Nepal has been struck by numerous major earthquakes

(Figure 3), some of which are the 1810, 1833, 1866, 1934, and 2015 earthquakes. Although there is little documentation on the extent of damage during these historical earthquakes, the 1934 earthquake damage is relatively well documented (Dixit et al., 2013) and as a recent devastating event, almost everything is well documented of the 2015 earthquake. In terms of the soil liquefaction in the Kathmandu Valley too, the surface manifestations during both these earthquakes were evident that different parts of the valley are quite prone to liquefaction damage.

According to a new seismic hazard map of Nepal (NBC, 2020) published by the Department of Urban Development and Building Construction (DUDBC), the PGA during an earthquake could be as high as $0.36 \mathrm{~g}$ to $0.4 \mathrm{~g}$ based on a probabilistic seismic hazard analysis with $10 \%$ probability of exceeding during the 50 years of study period. These PGA values are nearly double the highest acceleration value recorded in the Kathmandu Valley during the 2015 Gorkha Earthquake. 


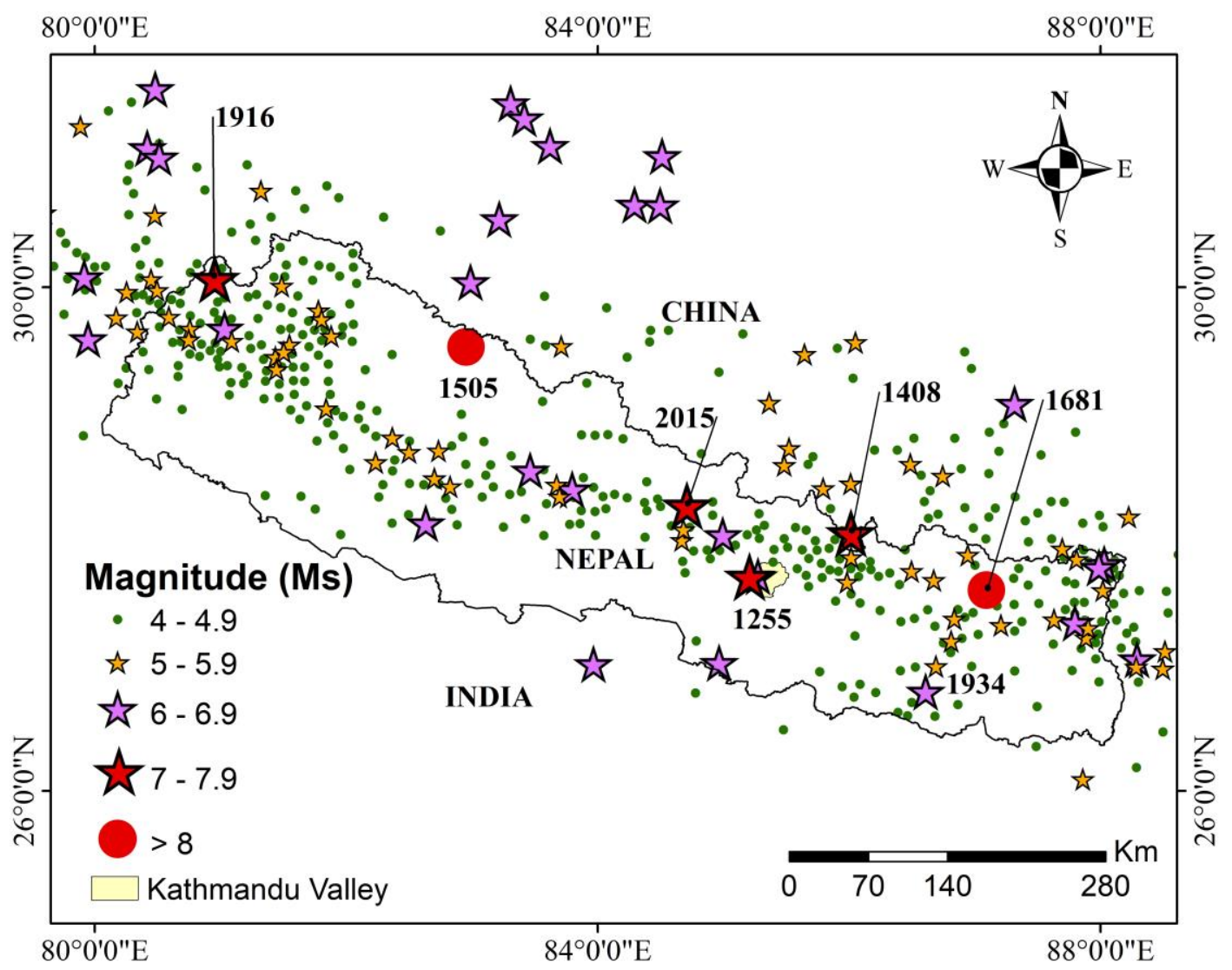

Figure 3. Earthquakes distribution in Nepal having magnitude $M_{\mathrm{S}} \geq 4.0$ during 1255-2015 AD (modified after Thapa et al. (2017))

\section{MATERIAL AND METHOD}

\subsection{BOREHOLE DATA AND GEOTECHNICAL CHARACTERIZATION}

Subsurface study of the valley was conducted using primary and secondary data. Ten boreholes were drilled to a depth of $20 \mathrm{~m}$ for primary data collection. Five boreholes were located in the central city area, while five were in liquefied sites during the 2015 Gorkha earthquake. As secondary data, 400 soil investigation reports containing geotechnical properties of soil of various 400 projects were used. The projects included residential buildings, public buildings, bridges, slope stability works and few others. For typical 400 projects, the total number of boreholes was 1500. The locations of data were spread all over the valley, as shown in Figure 1. Secondary data sources were soil test companies, SAFER data by the University of Bristol (Gilder et al., 2019) and other previous researches. To assess geotechnical characterization of the Kathmandu Valley, 
the authors have performed the SPT borehole drilling and logging, particle size distribution, plasticity chart, bedrock mapping, ground water level mapping and the study of liquefaction compositional criteria. The spatial mapping was done using ArcGIS platform whereas the graphical presentations were made with the use of Origin software.

\subsection{FACTOR OF SAFETY (FS) AGAINST SOIL LIQUEFACTION}

Idriss and Boulanger (2008) propounded an SPT-based method that was approved to analyze the FS. This technique predicts the FS against liquefaction for each layer based on SPT blow count data and geotechnical characteristics of the soil layers. This system specifies the cyclic resistance ratio (CRR) of the soils and the stress (loading) produced in the field as a result of a design earthquake. As a result, liquefaction occurs, which is quantified by the cyclic stress ratio (CSR). The FS to liquefaction ratio should be determined using Equation 1:

$$
F S=\frac{\mathrm{CRR}}{C S R}=\frac{C R R_{7.5} \times M S F \times K_{\sigma}}{C S R}
$$

where, $\mathrm{CRR}_{7.5}$ is the cyclic resistance ratio calibrated for the earthquake of $M_{\mathrm{w}} 7.5$; MSF is the magnitude scaling factor that accounts for the effects of shaking duration, and $\mathrm{K}_{\sigma}$ is a factor for the presence of sustained static shear stresses, such as may exist beneath foundations or within slopes.

MSF and $\mathrm{K}_{\sigma}$ were calculated using Equations 2 and 3

$$
\begin{gathered}
\mathrm{MSF}=6.9 \mathrm{e}^{-\frac{\mathrm{M}_{\mathrm{w}}}{4}}-0.058(\leq 1.8) \\
\mathrm{K}_{\sigma}=1-\mathrm{C}_{\sigma} \ln \left(\frac{\sigma_{\mathrm{v}}^{\prime}}{\mathrm{P}_{\mathrm{a}}}\right) \leq 1.1 \\
\mathrm{C}_{\sigma}=\frac{1}{18.9-2.55 \sqrt{\left(\mathrm{N}_{1}\right)_{60 \mathrm{cs}}}} \leq 0.3
\end{gathered}
$$

The SPT-N value derived from the field investigation was used to calculate the CRR. Equation 5 was used to correct the raw SPT-N value: 


$$
\left(\mathrm{N}_{1}\right)_{60}=\mathrm{NC}_{\mathrm{N}} \mathrm{C}_{\mathrm{E}} \mathrm{C}_{\mathrm{B}} \mathrm{C}_{\mathrm{R}} \mathrm{C}_{\mathrm{S}}
$$

where,

i) $\quad\left(\mathrm{N}_{1}\right)_{60}$ is the SPT blow count normalized to an overburden pressure of $100 \mathrm{kPa}$ (i.e. atmospheric pressure) with a hammer efficiency of $60 \%$.

ii) $\quad \mathrm{N}$ is the measured SPT blow count.

iii) $\quad \mathrm{C}_{\mathrm{N}}$ is the correction factor for overburden stress.

iv) $\quad \mathrm{C}_{\mathrm{B}}$ is the correction factor for borehole diameter.

v) $\quad C_{E}$ is the correction factor for the hammer energy ratio.

vi) $\quad C_{R}$ is the correction factor for rod length.

vii) $\mathrm{C}_{\mathrm{S}}$ is the correction factor for samplers with and without liners.

The $\mathrm{CRR}_{7.5}$ is calculated using Equation 6.

$$
\mathrm{CRR}_{7.5}=\exp \left(\frac{\left(\mathrm{N}_{1}\right)_{60 \mathrm{cs}}}{14.1}+\left(\frac{\left(\mathrm{N}_{1}\right)_{60 \mathrm{cs}}}{126}\right)^{2}-\left(\frac{\left(\mathrm{N}_{1}\right)_{60 \mathrm{cs}}}{23.6}\right)^{3}+\left(\frac{\left(\mathrm{N}_{1}\right)_{60 \mathrm{cs}}}{25.4}\right)^{4}-2.8\right)
$$

Where $\left(\mathrm{N}_{1}\right)_{60 \mathrm{cs}}$ is an equivalent clean-sand SPT blow count.

Equations 7 and 8 are used to calculate $\left(\mathrm{N}_{1}\right)_{60 \mathrm{cs}}$ :

$$
\begin{gathered}
\left(\mathrm{N}_{1}\right)_{60 \mathrm{cs}}=\left(\mathrm{N}_{1}\right)_{60}+\Delta\left(\mathrm{N}_{1}\right)_{60} \\
\Delta\left(\mathrm{N}_{1}\right)_{60}=\exp \left(1.63+\frac{9.7}{\mathrm{FC}+0.01}-\left(\frac{15.7}{\mathrm{FC}+0.01}\right)^{2}\right)
\end{gathered}
$$

where, FC is the fines content in the soils obtained from sieve analysis of the borehole or splitspoon samples.

The CSR is calculated by Equation 9:

$$
\operatorname{CSR}=0.65 \frac{\tau_{\max }}{\sigma^{\prime} \mathrm{vc}}=0.65 \frac{\sigma_{\mathrm{vc}}}{\sigma_{\mathrm{vc}}} \frac{\mathrm{a}_{\max }}{\mathrm{g}} \mathrm{r}_{\mathrm{d}}
$$

where, $\mathrm{a}_{\max }$ is the peak horizontal ground acceleration at the ground surface, $\mathrm{g}$ is the gravitational acceleration, $\sigma_{\mathrm{vc}}$ and $\sigma^{\prime}{ }_{\mathrm{vc}}$ are the total overburden stress and effective overburden stress, respectively, and $r_{d}$ is the stress reduction factor given by Equation 10: 


$$
\begin{array}{r}
r_{d}=\exp \left[-1.012-1.126 \sin \left(\frac{\mathrm{z}}{11.73}+5.133\right)\right. \\
\left.\quad+\mathrm{M}_{\mathrm{w}}\left(0.106+0.118 \sin \left(\frac{\mathrm{z}}{11.28}+5.142\right)\right)\right]
\end{array}
$$

Where: $\mathrm{z}$ is the depth of soil layer in meters.

\subsection{PROBABILITY OF LIQUEFACTION}

Soil liquefaction occurs in a deterministic framework when the FS is less than or equal to one. If FS $>1$, no soil liquefaction is anticipated. Due to the uncertainty in the model and soil parameters, FS > 1 may result in liquefaction depending on the variability in CSR and CRR. Indeed, it has been established that the liquefaction probability cannot be calculated merely by computing the FS. The calculation's inaccuracy is compounded by the uncertainty of the input parameters. A reliability analysis or probabilistic approach to liquefaction potential assessment may be beneficial as an alternative or addition to the deterministic evaluation.

To begin, the performance function is described using a reliability-based method. The inability to execute the stated function is determined by the performance value, which is either more than or less than a defined value under a specific situation. The limiting value of the performance function is defined as the value of the performance function that was used in the analysis. The CSR is indicated by ' $S$ ' in the simplified liquefaction assessment technique employed in this research, whereas the CRR is denoted by 'R'. Equation 11 is used to compute the liquefaction performance function:

$$
\mathrm{Z}=\mathrm{R}-\mathrm{S}
$$

When $\mathrm{Z}$ is less than one or $\mathrm{R}$ is less than $\mathrm{S}$, liquefaction occurs, which is referred to as 'failure.' If $\mathrm{Z}$ exceeds one or $\mathrm{R}$ exceeds $\mathrm{S}$, the output is considered to be 'safe,' meaning that no liquefaction will occur. When the value of $\mathrm{Z}$ equals one, the score is considered to be at the 'limit' phase. This implies that the output is on the verge of liquefaction. Both $\mathrm{S}$ and $\mathrm{R}$ are referred to as independent random variables due to their inherent uncertainty. As a result, $\mathrm{Z}$ is frequently considered to be a random variable. The probability of liquefaction $\left(P_{\mathrm{L}}\right)$ is defined as the probability that $\mathrm{Z}$ is less than 1 or $\mathrm{R}$ is smaller than $\mathrm{S} . \mathrm{Z}$ statistics are calculated in this analysis using the FOSM method. 
This is concerned with independent random variables, most commonly referred to as $\mathrm{R}$ and $\mathrm{S}$ statistics. According to statistical theory, if all $\mathrm{R}$ and $\mathrm{S}$ are independent random variables subject to the normal distribution, the normal distribution is said to respect the output function vector $\mathrm{Z}$. Next, the $P_{\mathrm{L}}$ is given as in Equation 12,

$$
P_{\mathrm{L}}=P_{\mathrm{L}}(\mathrm{Z} \leq 0)=\int_{-\infty}^{\infty} \mathrm{fz}(\mathrm{z})=\mathrm{F}_{\mathrm{z}}(0)
$$

where, $\mathrm{Z}$ is cumulative probability function $(\mathrm{CPF})$ given as $\mathrm{F}_{\mathrm{z}}(\mathrm{z})$, and $\mathrm{f}_{\mathrm{z}}(\mathrm{z})$ is probability density function.

Now, the mean $(\mu \mathrm{z})$, standard deviation $\left(\sigma_{\mathrm{z}}\right)$, and $\operatorname{COV}\left(\mathrm{V}_{\mathrm{z}}\right)$ of the performance function, $\mathrm{Z}$, are expressed as below (Equation 13-15):

$$
\begin{gathered}
\mu_{\mathrm{Z}}=\mu_{\mathrm{R}}-\mu_{\mathrm{S}} \\
\sigma_{\mathrm{z}}=\sqrt{\sigma_{\mathrm{R}}^{2}+\sigma_{\mathrm{S}}^{2}} \\
\mathrm{COV}=\frac{\sigma_{\mathrm{z}}}{\mu_{\mathrm{z}}}=\frac{\sqrt{\left(\sigma_{\mathrm{R}}^{2}+\sigma_{\mathrm{S}}{ }^{2}\right)}}{\left(\mu_{\mathrm{R}}-\mu_{\mathrm{S}}\right)}
\end{gathered}
$$

where, $\sigma_{\mathrm{R}}, \sigma_{\mathrm{S}}, \mu_{\mathrm{R}}$, and $\mu_{\mathrm{S}}$ are the standard deviations and mean values of $\mathrm{R}$ and $\mathrm{S}$, respectively.

Based on calculated probability, the possibility of liquefaction is identified using Table 1.

Table 1. Liquefaction occurrence based on $P_{\mathrm{L}}$ value (Chen and Juang, 2000).

\begin{tabular}{lll}
\hline Probability & Possibility of Liquefaction & Class \\
\hline $0.85 \leq P_{\mathrm{L}}$ & Almost certain that it will liquefy & 5 \\
$0.65 \leq P_{\mathrm{L}}<0.85$ & Very likely & 4 \\
$0.35 \leq P_{\mathrm{L}}<0.65$ & Liquefaction/non-liquefaction is equally & 3 \\
& likely & 2 \\
$0.15 \leq P_{\mathrm{L}}<0.35$ & Unlikely & 1 \\
$P_{\mathrm{L}}<0.15$ & Almost certain that it will not liquefy & 1 \\
\hline
\end{tabular}




\subsection{FIRST-ORDER SECOND-MOMENT METHOD (FOSM)}

The FOSM technique is the simplest and most often used method for estimating a dependent variable's variability as a function of the variances of its input variables. The FOSM method evaluates the function using a Taylor series extension. This may be used to determine the mean and coefficient of variation of CSR and CRR. The mean and COV values of the CSR are computed using Equations 16 and 17.

$$
\begin{gathered}
\mu_{\mathrm{CSR}}=0.65 \frac{\mu_{\mathrm{a}_{\max }}}{\mathrm{g}} \frac{\mu_{\sigma_{\mathrm{v}}}}{\mu_{\sigma_{\mathrm{v}}}} \mu_{\gamma_{\mathrm{d}}} \\
\mathrm{V}_{\mathrm{CSR}}^{2}=\mathrm{V}_{0.65 \text { factor }}^{2}+\mathrm{V}_{\mathrm{a}_{\max }}^{2}+\mathrm{V}_{\sigma_{\mathrm{v}} / \sigma{ }_{\mathrm{v}}}^{2}+\mathrm{V}_{\gamma_{\mathrm{d}}}^{2}
\end{gathered}
$$

where, $\mu$ and $\mathrm{V}$ represents the respective mean and COV.

Table 2. Christian and Baecher (2016) given COV values of input parameters

\begin{tabular}{ll}
\hline Parameters & $\mathbf{C O V}(\mathbf{V})$ \\
\hline $\mathrm{MSF}$ & 0.2 \\
\hline 0.65 Factor & 0.05 \\
$\mathrm{~K}_{\sigma}$ & 0.07 \\
$\mathrm{a}_{\max }$ & 0.1 \\
$\sigma_{\mathrm{v}} / \sigma_{\mathrm{v}}{ }^{\prime}$ & 0.05 \\
$\mathrm{~N}$ & 0.1 \\
$\gamma_{\mathrm{d}}$ & 0.2 \\
$\mathrm{C}_{B}$ & 0.02 \\
$\mathrm{C}_{R}$ & 0.02 \\
$\mathrm{C}_{\mathrm{E}}$ & 0.02 \\
$\mathrm{C}_{\mathrm{N}}$ & 0.02 \\
$\mathrm{CS}_{S}$ & 0.02
\end{tabular}

On the basis of past experiments and thorough laboratory and computational analysis, the COVs of input parameters may be calculated. The COVs assumed for various input parameters used to estimate CSR and CRR in this study are derived from Christian and Baecher (2016), as indicated in Table 2. COVs for dependent variables may be computed using the equations in Table 3. 
Table 3. COVs taken for dependent variables

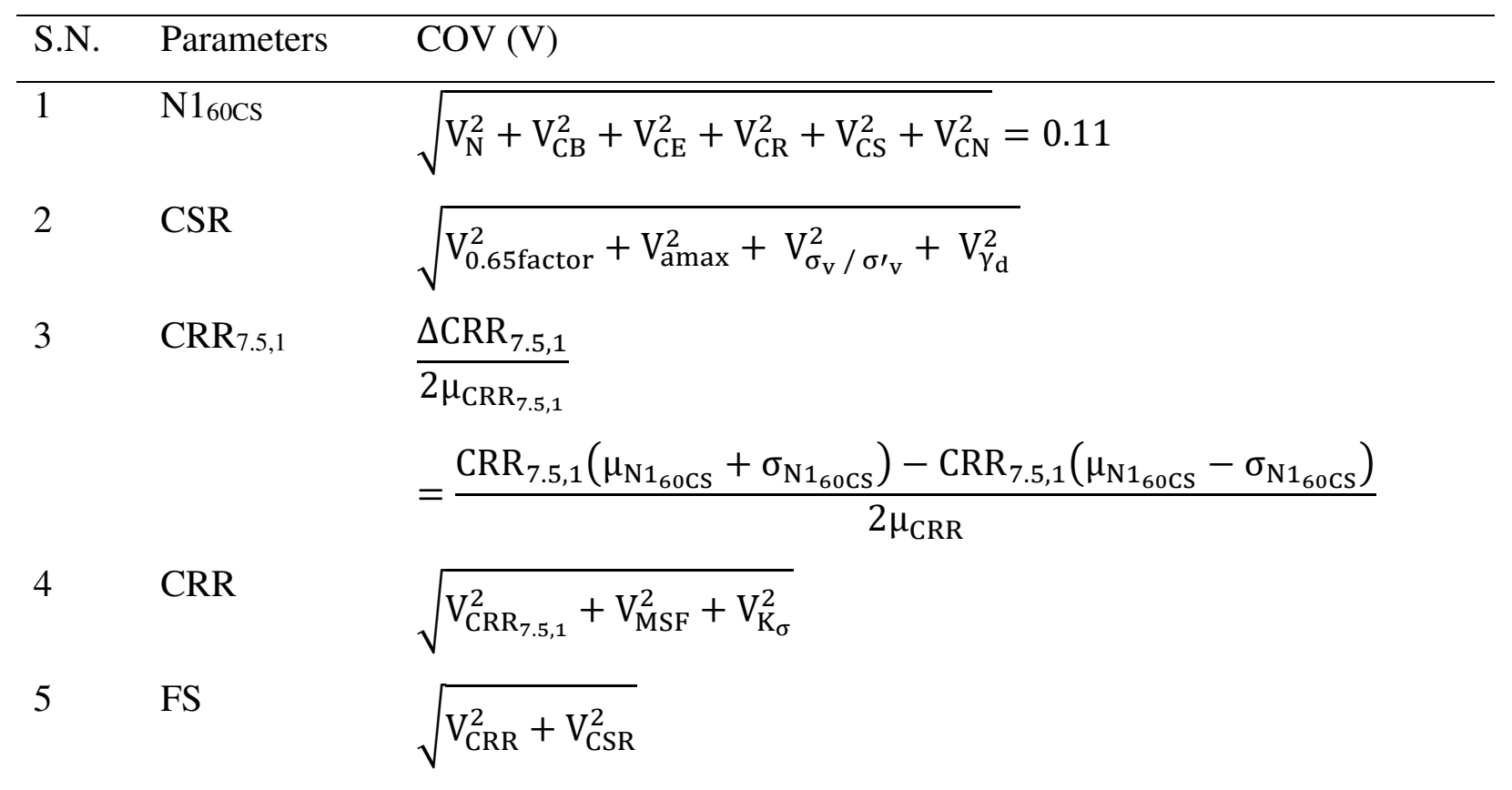

\subsection{RELIABILITY ANALYSIS OF SOIL LIQUEFACTION}

In reliability analysis, the susceptibility of soil liquefaction is frequently stated in terms of the likelihood of liquefaction. The risk of liquefaction is stated in terms of the probability of liquefaction, $P_{\mathrm{L}}$, which is calculated using the reliability index $\beta$ as defined in Equation 18:

$$
P_{\mathrm{L}}=\varphi(-\beta)=1-\varphi(\beta)
$$

where, $\varphi()$ is the standard normal cumulative probability. Considering FS follows lognormal probability distribution (Duncan, 2000; Hwang et al., 2004), $\beta$ is defined as (Equation 19):

$$
\beta_{\mathrm{LN}}=\frac{\ln \left[\frac{\mu_{\mathrm{FS}}}{\sqrt{1+\mathrm{V}_{\mathrm{FS}}^{2}}}\right]}{\sqrt{\ln \left(1+\mathrm{V}_{\mathrm{FS}}^{2}\right)}}
$$

The sample calculation to assess $P_{\mathrm{L}}$ using probabilistic-reliability analysis based on FOSM is given in Table 4. The calculation presented in the table is of borehole named 'Balkumari_BH1' which represents first borehole of location Balkumari $\left(27.6695^{\circ} \mathrm{N}, 85.3408^{\circ} \mathrm{E}\right)$. For each location, a reliability index is determined, and the liquefaction probability is estimated. Even at FS $>1$, the 
percentage of liquefaction likelihood is large, according to this method. It backs up the findings of Jha and Suzuki (2009b) that the deterministic safety factor isn't the only factor to consider when assessing liquefaction risk.

Table 4. Typical calculation sheet of Liquefaction probability $\left(P_{\mathrm{L}}\right)$ using reliability analysis

\begin{tabular}{lllllll}
\hline Borehole Name & Depth $(\mathbf{m})$ & CSR & CRR & FS & $\boldsymbol{\beta}$ & $\boldsymbol{P}_{\mathbf{L}}(\boldsymbol{\%})$ \\
\hline Balkumari_BH1 & 1.5 & 0.117 & 0.125 & 1.07 & -0.062 & 0.525 \\
& 3 & 0.142 & 0.147 & 1.03 & -0.165 & 0.565 \\
& 4.5 & 0.164 & 0.130 & 0.79 & -0.742 & 0.771 \\
& 6 & 0.177 & 0.123 & 0.69 & -1.040 & 0.851 \\
& 7.5 & 0.184 & 0.126 & 0.69 & -1.059 & 0.855 \\
& 9 & 0.188 & 0.114 & 0.61 & -1.359 & 0.913 \\
& 10.5 & 0.190 & 0.119 & 0.63 & -1.271 & 0.898 \\
& 12 & 0.190 & 0.123 & 0.65 & -1.183 & 0.882 \\
& 13.5 & 0.189 & 0.127 & 0.67 & -1.095 & 0.863 \\
& 15 & 0.188 & 0.116 & 0.62 & -1.297 & 0.903 \\
& 16.5 & 0.186 & 0.107 & 0.58 & -1.493 & 0.932 \\
& 18 & 0.183 & 0.105 & 0.57 & -1.514 & 0.935 \\
\hline
\end{tabular}

\section{RESULTS AND DISCUSSIONS}

\subsection{GEOTECHNICAL CHARACTERIZATION}

Figure 4 illustrates the typical soil profiles at six places where the liquefaction phenomenon was seen during the 2015 Gorkha earthquake. The picture depicts the heterogeneous soil layer strata, which are characterized by a high proportion of silt and sand layers. Also, the observed liquefaction at these six sites is presented in Figure 5.

In addition, the particle size distribution of the Kathmandu subsoils is presented in Figure 6. According to the particle size study, the most frequent soil types in the valley are observed as sand and silt. It supports the fact that Kathmandu valley was once a lake and had a lacustrine and fluvial origin. Additionally, two sets of particle size curves illustrating the distribution ranges for the most 
liquefiable and potentially liquefiable soils given by Tsuchida and Hayashi (1972) are also plotted (Figure 6). It shows that sand or silty sands are mostly liquefiable, whereas silts with a lower liquid limit may liquefy. Figure 6 shows that particle size distribution of the valley is higher inside the potentially liquefiable soil boundary and highest inside the edge of most liquefiable soil which clearly suggests that soil in Kathmandu has deposits that are very susceptible to liquefaction.

Moreover, the plasticity index is found in the range of $1.73 \%$ - $34 \%$, with most soils having $10 \%$ - 20\% plasticity values as shown in Casagrande chart (based on Casagrande (1947)) for all cohesive soils taken for this study (Figure 7). It reveals that the majority of fine-grained soils include silt with moderate to high swelling properties, which is essential for liquefaction evaluation since silts with low plasticity are often more sensitive to seismic motion (Bray and Sancio, 2006). The bedrock depth variation inside the valley is represented in Figure 8. The interpolation was performed in ArcGIS using the 56 lithologs data drilled up to bedrock performed by the Department of Mines and Geology (DMG). The bedrock depth ranges between $70 \mathrm{~m}$ and $575 \mathrm{~m}$. The groundwater table (GWT) mapping of the valley is depicted in Figure 9. For the study, the GWT was taken as minimum of depth observed from borehole log information and GWT map prepared by Shrestha et al. (2016). The minimum GWT observed is usually shallow in the valley, ranging between $0.5 \mathrm{~m}$ and $5 \mathrm{~m}$ below the earth surface. 

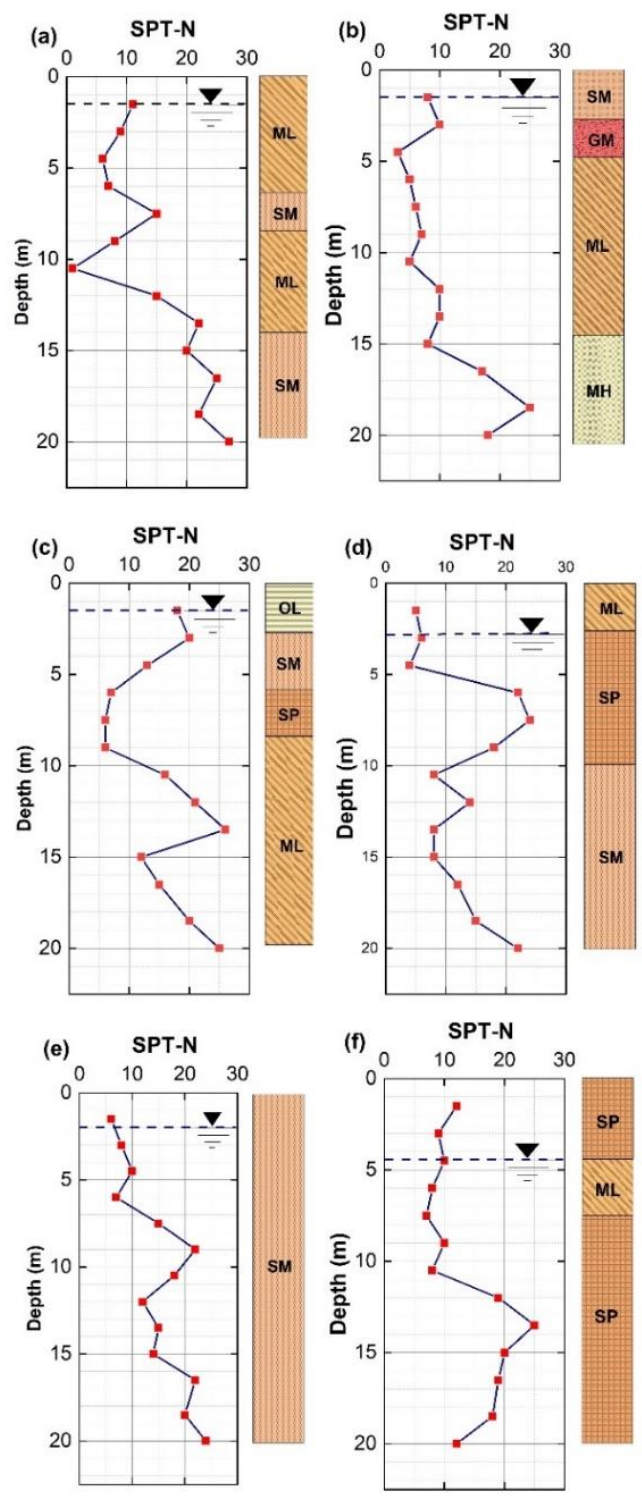

Figure 4. The typical soil profile of borehole at (a) Manamaiju $\left(27.7453^{\circ} \mathrm{N}, 85.3007^{\circ} \mathrm{E}\right)$ (b) Imadol $\left(27.6668^{\circ} \mathrm{N}, 85.3383^{\circ} \mathrm{E}\right)$ (c) Ramkot $\left(27.7110^{\circ} \mathrm{N}, 85.2622^{\circ} \mathrm{E}\right)$ (d) Bungamati $\left(27.6222^{\circ} \mathrm{N}, 85.2622^{\circ} \mathrm{E}\right)\left(\right.$ e) $\mathrm{NEC}$ Changunarayan $\left(27.709^{\circ} \mathrm{N}, 85.414^{\circ} \mathrm{E}\right)$ (f) Mulpani $\left(27.7025^{\circ} \mathrm{N}\right.$, $85.7005^{\circ} \mathrm{E}$ ) with variation of SPT with depth. 

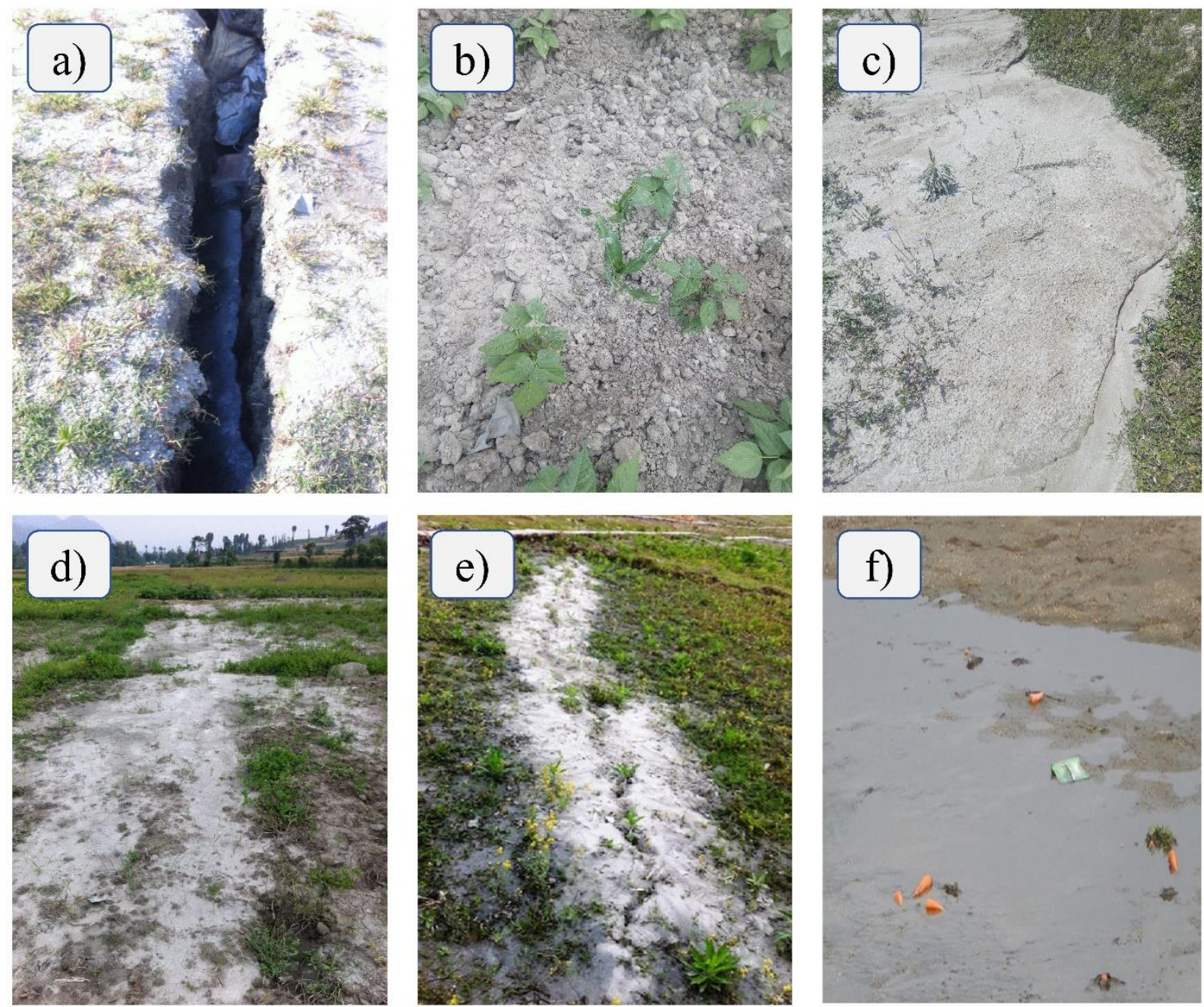

Figure 5. Observed liquefaction at (a) Manamaiju (b) Imadol (c) Ramkot (d) Bungmati (e) Changunarayan NEC (f) Mulpani 


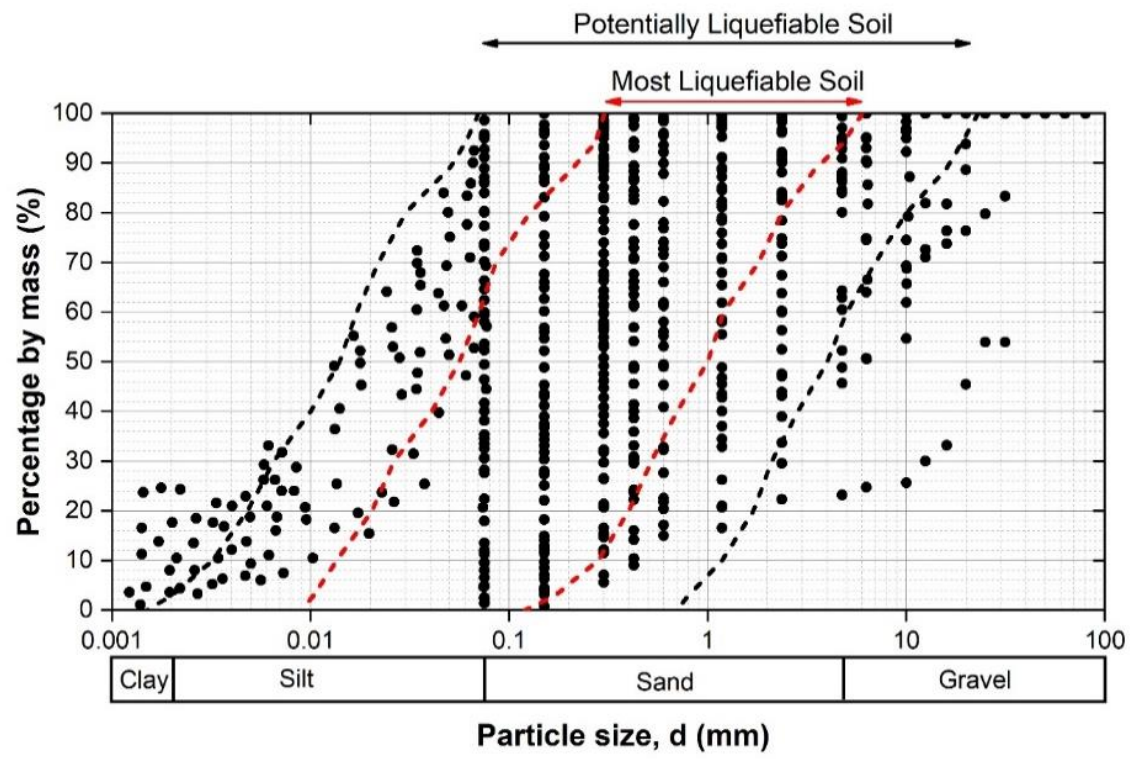

Figure 6. Particle size distribution with a range of liquefiable soils given by Tsuchida and Hayashi (1972)

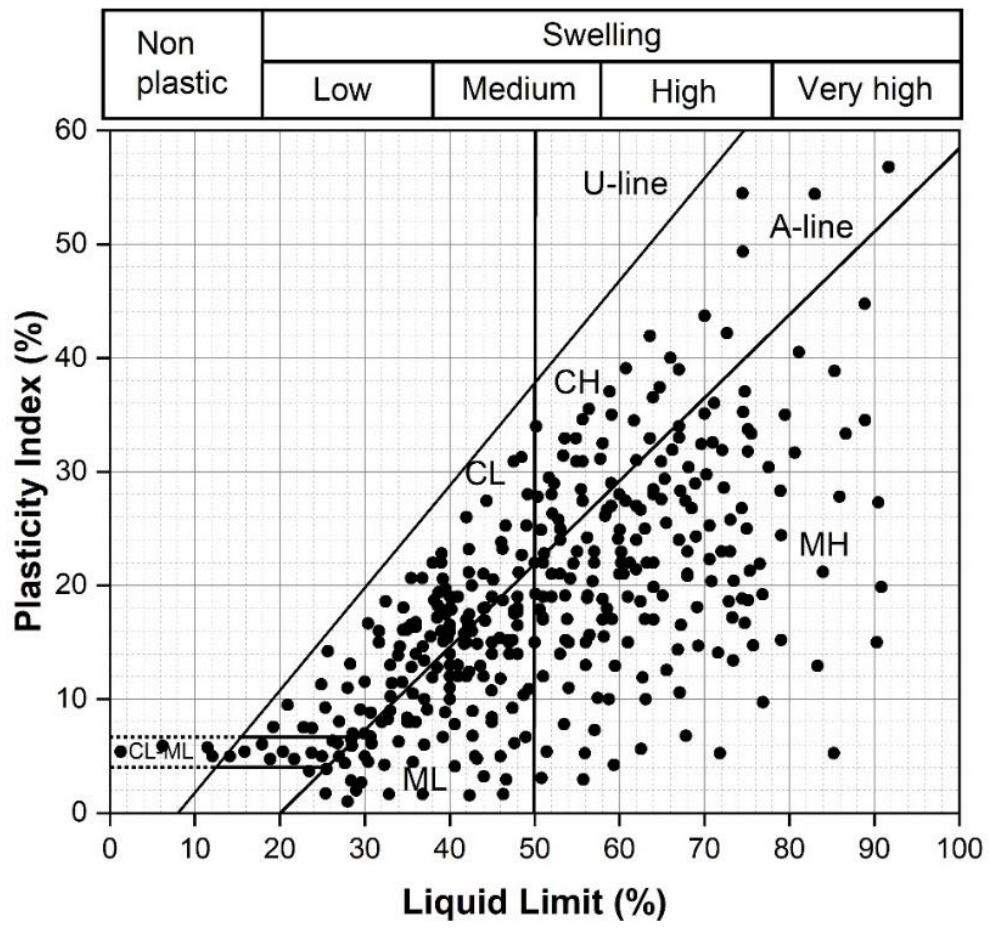

Figure 7. Fine-grained soils plotted in Casagrande's plasticity chart based on Casagrande (1947) 


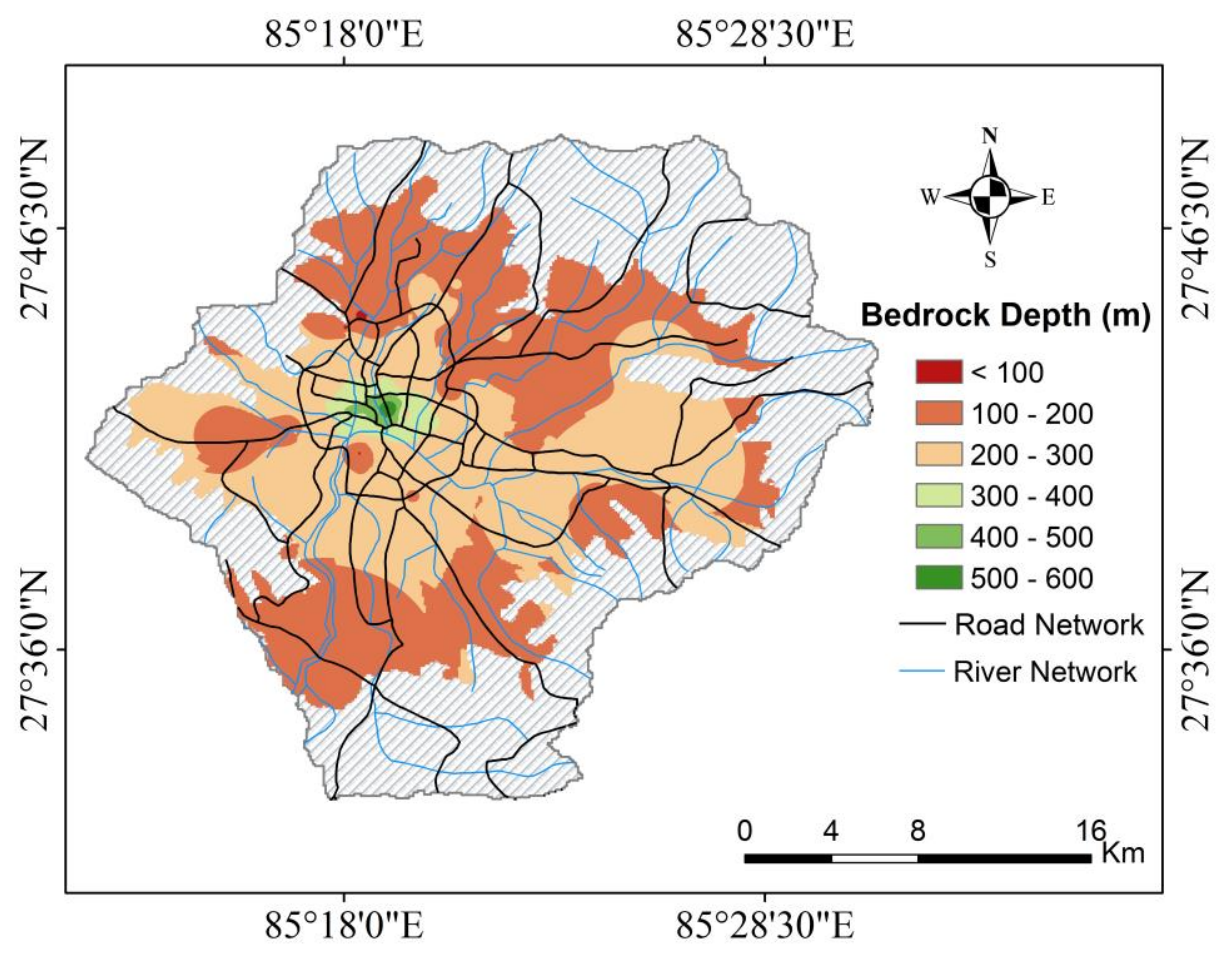

Figure 8. Variation of bedrock depth in Kathmandu Valley

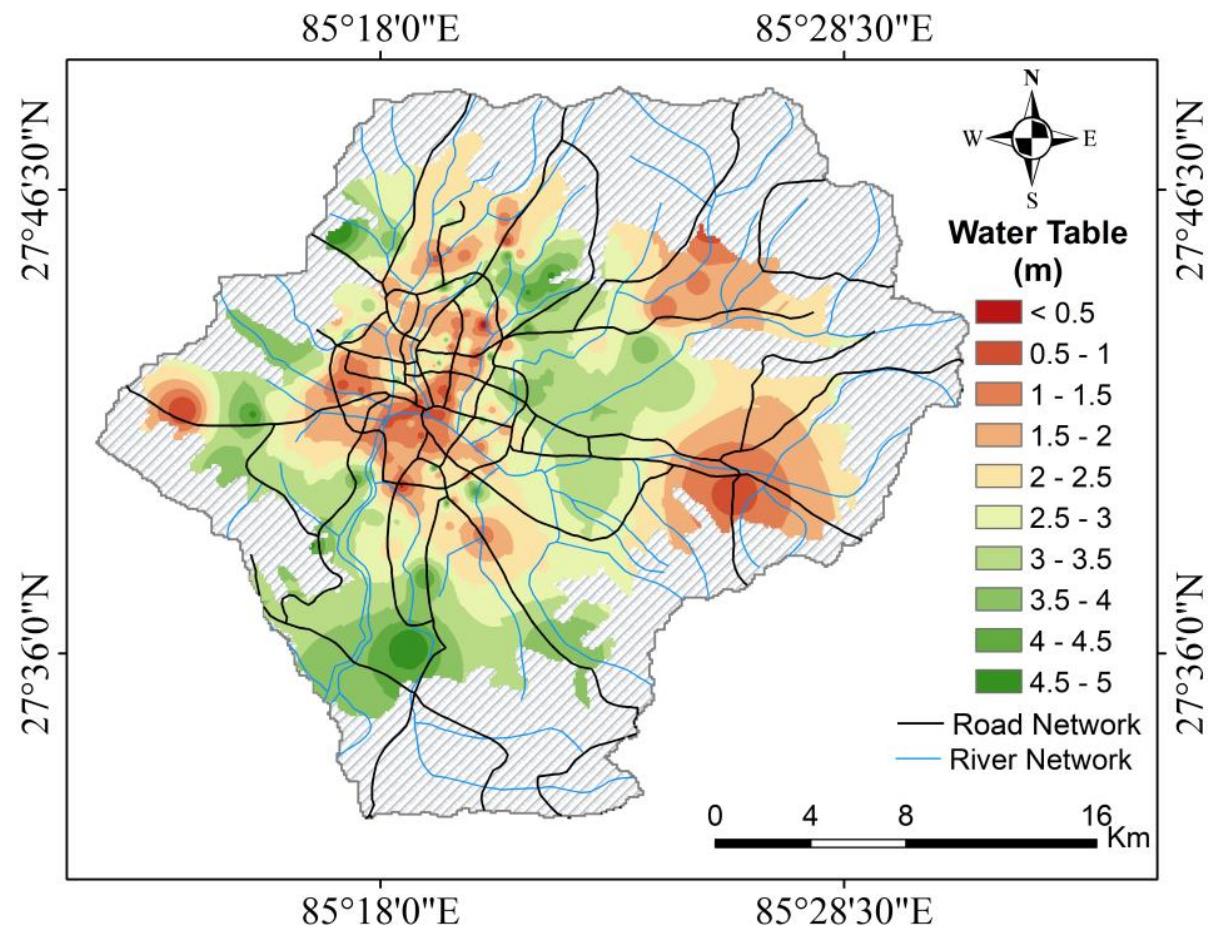

Figure 9. Water table variation map of the Kathmandu Valley 
Excessive pore water pressure production causes liquefaction, which is directly related to the compositional properties of the soil. Bray and Sancio (2006) suggested the compositional parameters for liquefaction susceptibility shown in Table 5 based on water content $\left(w_{\mathrm{c}}\right)$, liquid limit (LL), and plasticity index (PI).

Table 5. Liquefaction susceptibility due to compositional criteria by Bray and Sancio (2006).

\begin{tabular}{ll}
\hline Criteria & Liquefaction Susceptibility \\
\hline $\mathrm{PI} \leq 12$ and $\left(w_{\mathrm{c}} / \mathrm{LL}\right) \geq 0.85$ & High \\
$12 \leq \mathrm{PI} \leq 18$ and $0.85>\left(w_{\mathrm{c}} / \mathrm{LL}\right) \geq 0.80$ & Moderate \\
$\mathrm{PI}>18$ and $\left(w_{\mathrm{c}} / \mathrm{LL}\right)<0.80$ & No \\
\hline
\end{tabular}

This criteria was extended to soil samples from all 1500 secondary and ten primary borehole data using physical and shear parameters of the Kathmandu subsoil. The graphical plots are shown in Figure 10. In this study, the depth ranges of (a) 0-5m, (b) $5-10 \mathrm{~m}$, (c) 10-15m, (d) $15 \mathrm{~m}$, and (e) > $15 \mathrm{~m}$ are investigated. And, the investigation shows that the soil samples in the depth ranges of 0$5 \mathrm{~m}, 5-10 \mathrm{~m}$, and 10-15m are more liquefiable than soil samples in depth ranges greater than $15 \mathrm{~m}$, which may be attributed to sediment consolidation due to overburden pressure. 

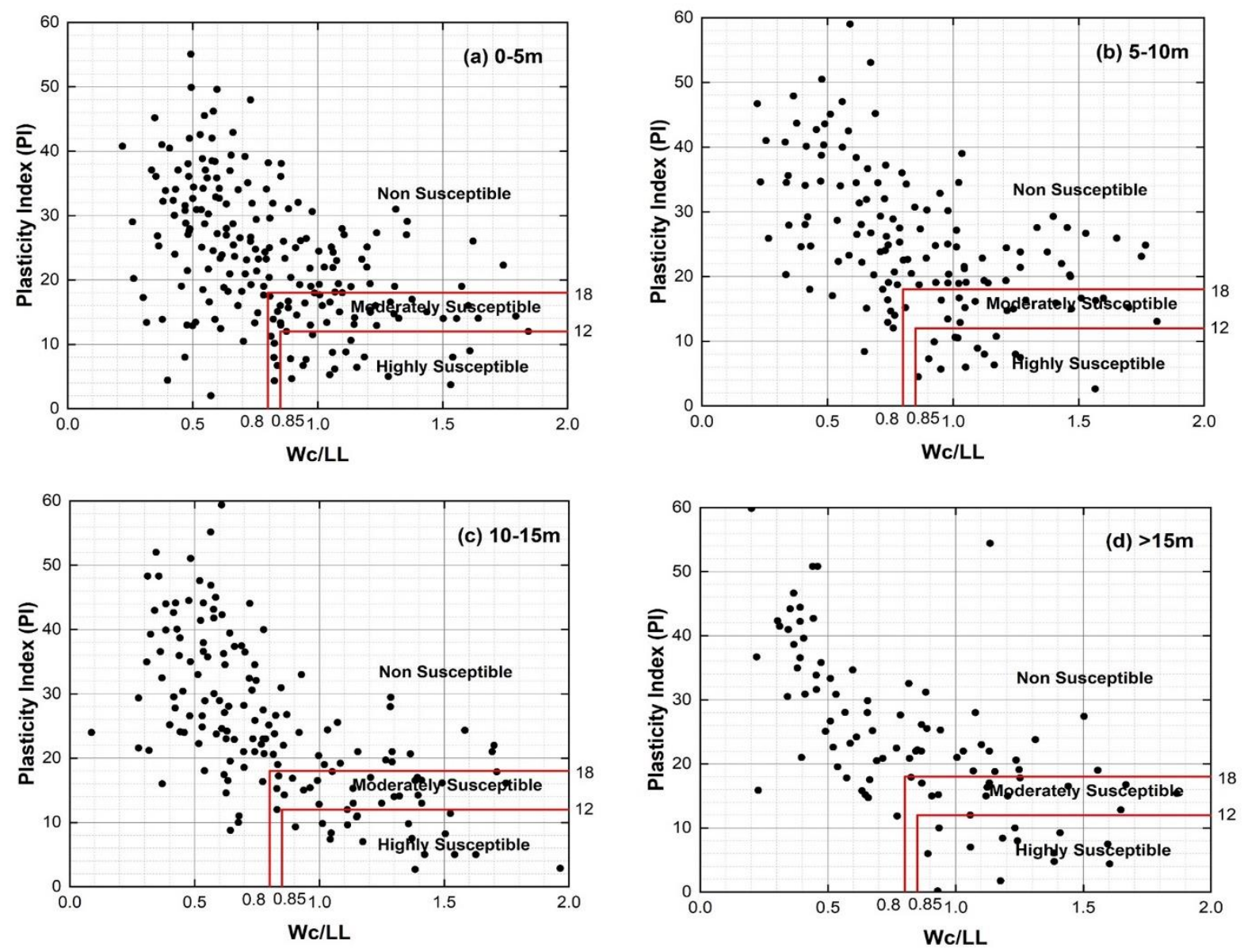

Figure 10. Plasticity Index vs $w_{\mathcal{C}} / \mathrm{LL}$ with Bray and Sancio (2006) proposed liquefaction susceptibility criteria, for depth ranges of (a) $0-5 \mathrm{~m}$ (b) $5-10 \mathrm{~m}$ (c) $10-15 \mathrm{~m}$ (d) $>15 \mathrm{~m}$

\subsection{PROBABILITY OF LIQUEFACTION $\left(P_{\mathrm{L}}\right)$}

A liquefaction probability curve corresponding to the FS for all the boreholes for three likely-torecur scenario earthquakes, i.e., $M_{\mathrm{w}} 7.8(0.18 \mathrm{~g}), M_{\mathrm{w}} 8.0(0.30 \mathrm{~g})$ and $M_{\mathrm{w}} 8.4(0.36 \mathrm{~g})$ is shown in Figure 11. Indeed, it has been observed that the $M_{\mathrm{w}} 8.4(0.36 \mathrm{~g})$ earthquake scenario demonstrates a high liquefaction probability in comparison to the $M_{\mathrm{w}} 7.8(0.18 \mathrm{~g})$ and $M_{\mathrm{w}} 8.0(0.30 \mathrm{~g})$. However, when FS < 1, the $M_{\mathrm{w}} 7.8(0.18 \mathrm{~g})$ earthquake shows a slightly higher probability than the other two. The graphical results were validated with the previous similar study made by Singnar and Sil (2018) for liquefaction potential assessment of Guwahati city, India. 


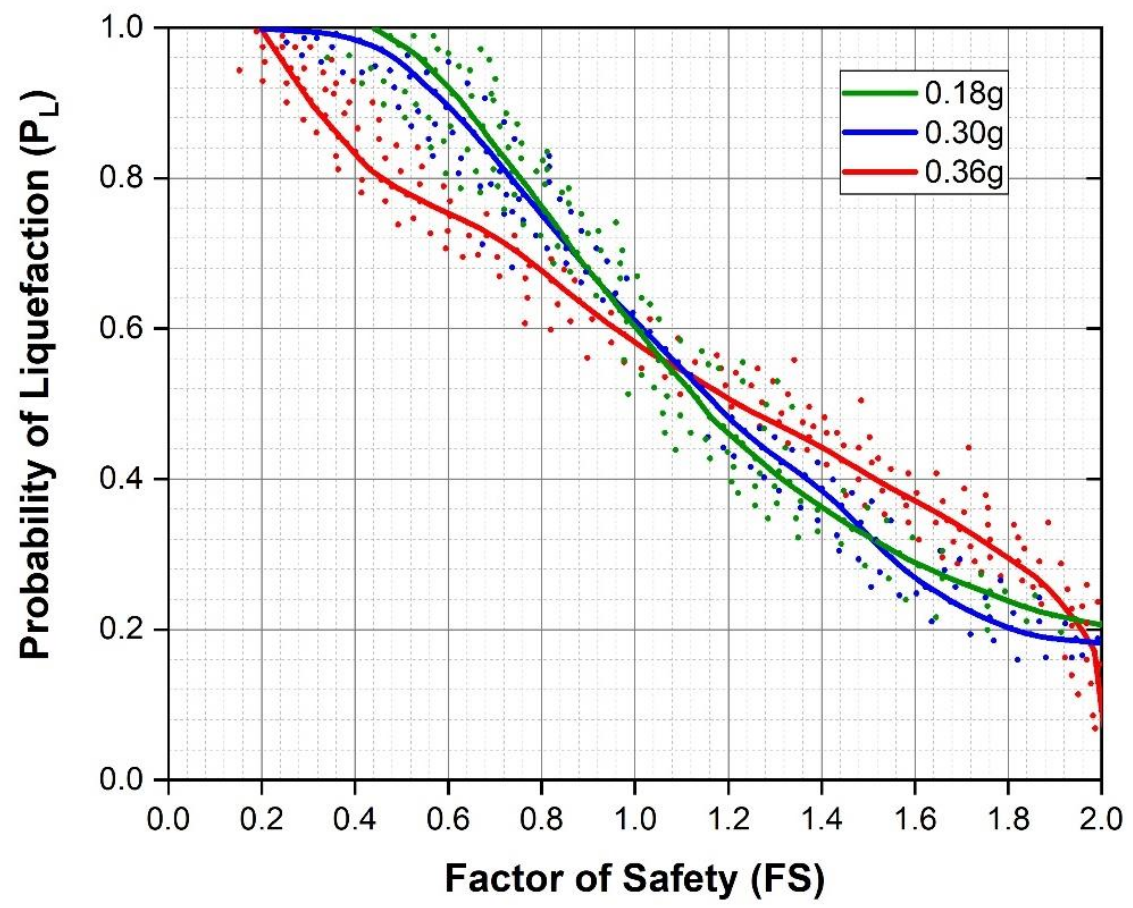

Figure 11. $P_{\mathrm{L}}$ vs. FS graph for $M_{\mathrm{w}} 7.8(0.18 \mathrm{~g}), M_{\mathrm{w}} 8.0(0.30 \mathrm{~g})$ and $M_{\mathrm{w}} 8.4(0.36 \mathrm{~g})$ with respective data points. 

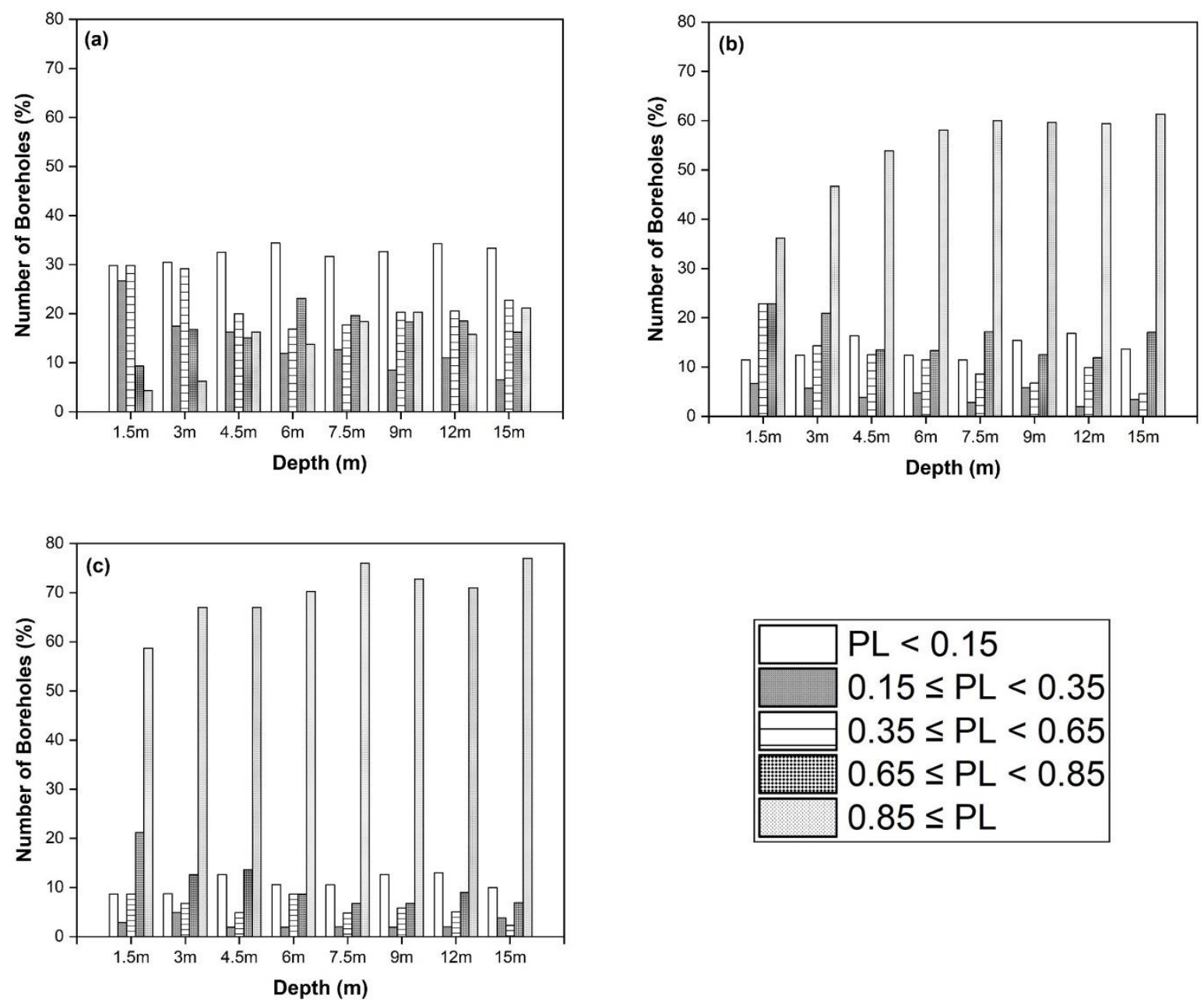

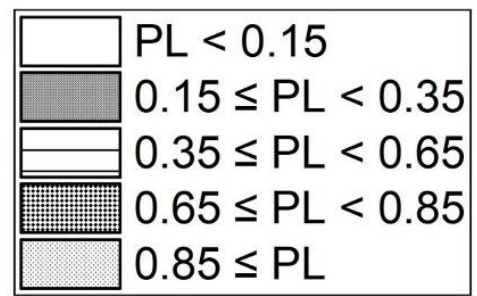

Figure 12. Number of boreholes with probability range given by (Chen and Juang, 2000) in different depths for earthquake scenario of (a) $M_{\mathrm{w}} 7.8$ (0.18g PGA) (b) $M_{\mathrm{w}} 8.0$ (0.30g PGA), and (c) $M_{\mathrm{w}} 8.4(0.36 \mathrm{~g}$ PGA)

Based on different liquefaction occurrence scenario given by Chen \& Juang (2000), as shown in Table 2, the number of boreholes lying in various classes of probability for three earthquake scenarios are presented in Figure 12. For the $M_{\mathrm{w}} 7.8(0.18 \mathrm{~g})$ scenario earthquake, most boreholes fall under unlikely to liquefaction classes for all depths (Figure 12 (a)). The percentage of boreholes with the certainty of liquefaction is a minimum of $4.35 \%$ at $1.5 \mathrm{~m}$ depth and $21.14 \%$ at $5 \mathrm{~m}$ depth. This result correlates the occurrence of liquefaction in Kathmandu valley during the 2015 Gorkha, Nepal earthquake with the same magnitude of the shaking observed by Sharma et 
al. (2019). Conversely, the number of boreholes having the certainty of liquefaction $\left(P_{\mathrm{L}} \geq 0.85\right)$ is the highest among all classes of probability for $M_{\mathrm{w}} 8.0(0.30 \mathrm{~g})$ and $M_{\mathrm{w}} 8.4(0.36 \mathrm{~g})$ earthquakes. With an increase in magnitude and PGA of earthquake scenarios, the number of locations having $0.35 \leq P_{\mathrm{L}}<0.85$ and $P_{\mathrm{L}} \geq 0.85$ has increased. Around 36 to $61 \%$ of the borehole locations for $M_{\mathrm{w}} 8.0(0.30 \mathrm{~g})$ and 58 to $77 \%$ for $M_{\mathrm{w}} 8.4(0.36 \mathrm{~g})$ have a high probability of occurrence of liquefaction (Figure 10(b) and 10(c)).
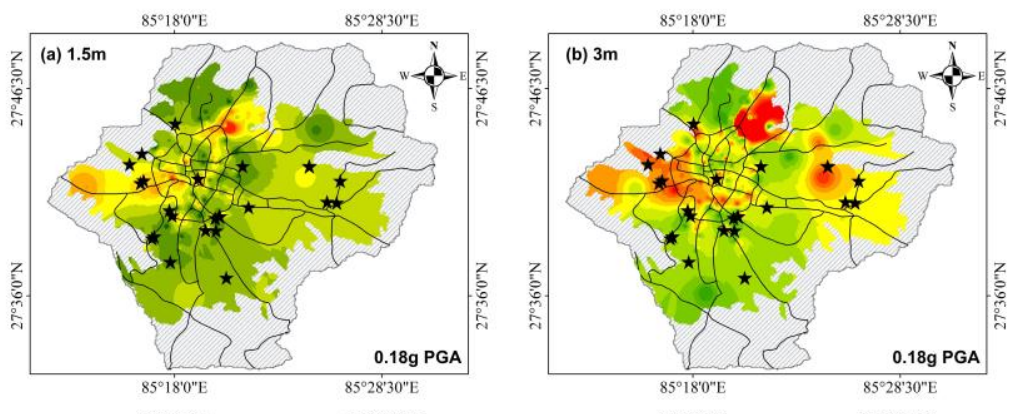

PL

C $<0.05$

$0.05-0.1$
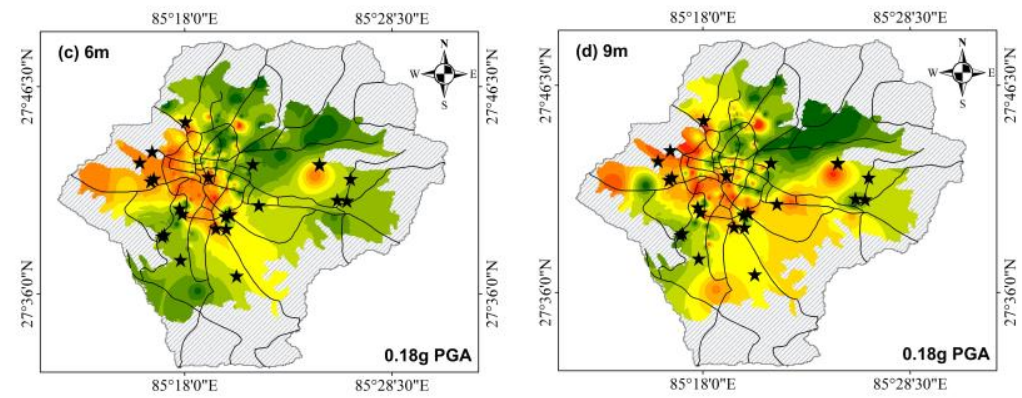

$0.1-0.2$

$\square .2-0.3$

$\square 0.3-0.4$

$\square 0.4-0.5$

$\square 0.5-0.6$

$\square 0.6-0.7$

$\square 0.7-0.8$

$0.8-0.9$

$0.9-1.0$

Bedrock
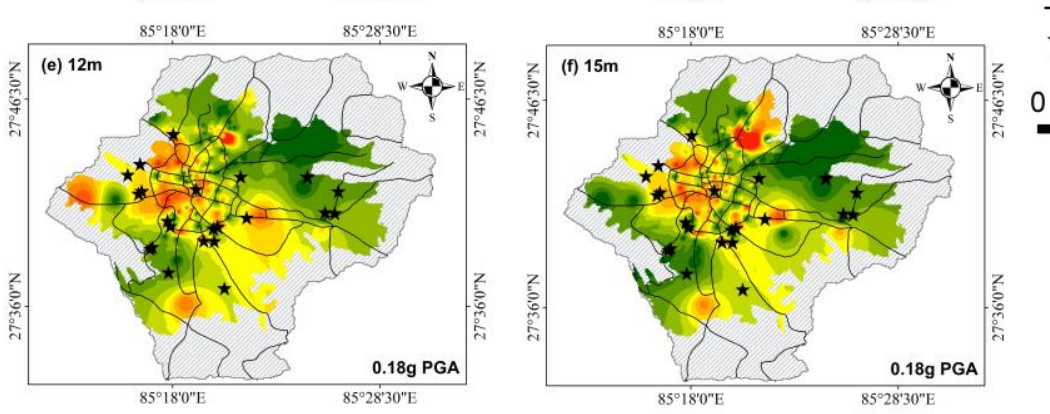

- Road Network

$\star 2015$ Eq. Liquefied Sites

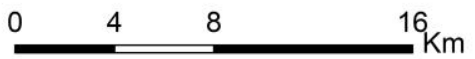

Figure 13. Maps showing the variation of $P_{\mathrm{L}}$ against liquefaction for $M_{\mathrm{w}} 7.8$ with $a_{\max }$ of $0.18 \mathrm{~g}$ at depths a) $1.5 \mathrm{~m}$, b) $3 \mathrm{~m}$, c) $6 \mathrm{~m}$, d) $9 \mathrm{~m}$, e) $12 \mathrm{~m}$, and f) $15 \mathrm{~m}$ 

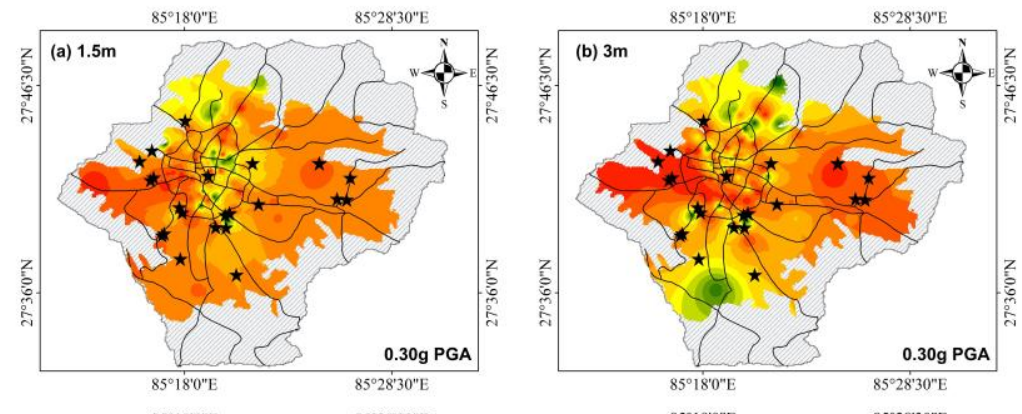

PL
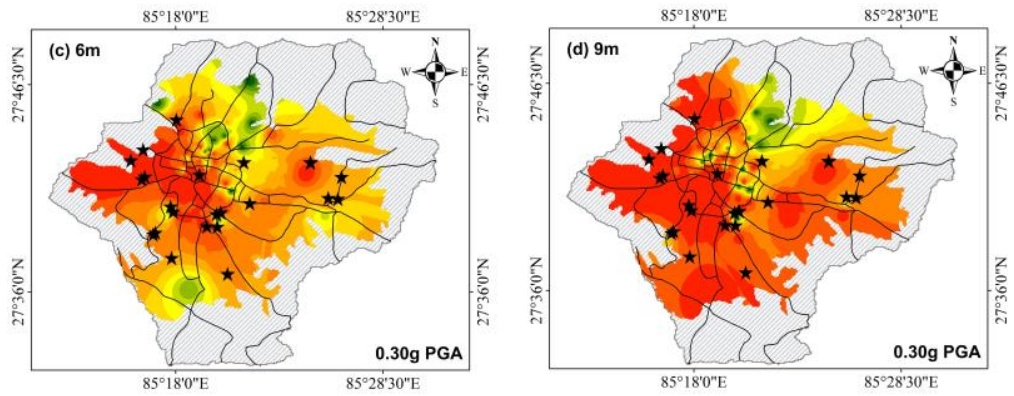

$<0.05$
$0.05-0.1$
$0.1-0.2$

$\square .2-0.3$

$\square 0.3-0.4$

$\square 0.4-0.5$

$\square 0.5-0.6$

$\square 0.6-0.7$

$\square 0.7-0.8$

$0.8-0.9$

$0.9-1.0$

Bedrock
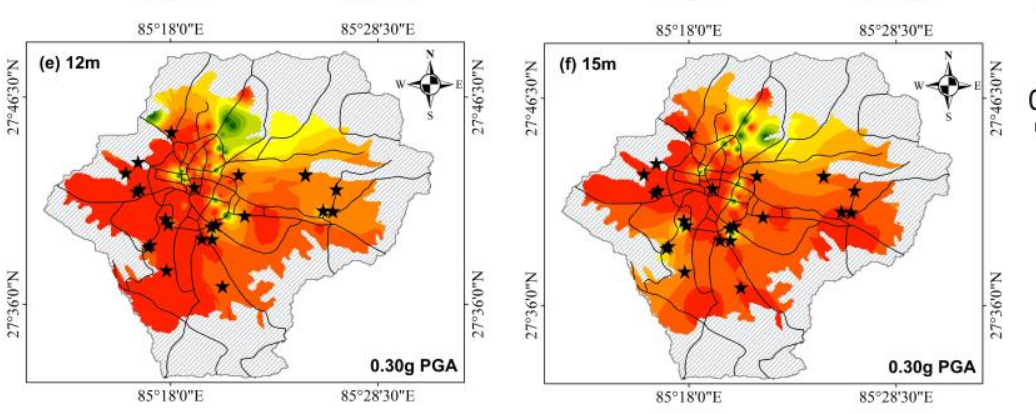

- Road Network

$\star 2015$ Eq. Liquefied Sites

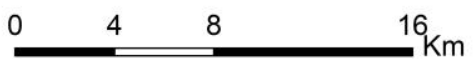

Figure 14. Maps showing the variation of $P_{\mathrm{L}}$ against liquefaction for $M_{\mathrm{w}} 8.0$ with $a_{\max }$ of $0.30 \mathrm{~g}$ at depths a) $1.5 \mathrm{~m}$, b) $3 \mathrm{~m}$, c) $6 \mathrm{~m}, \mathrm{~d}$ ) $9 \mathrm{~m}$, e) $12 \mathrm{~m}$, and f) $15 \mathrm{~m}$ 

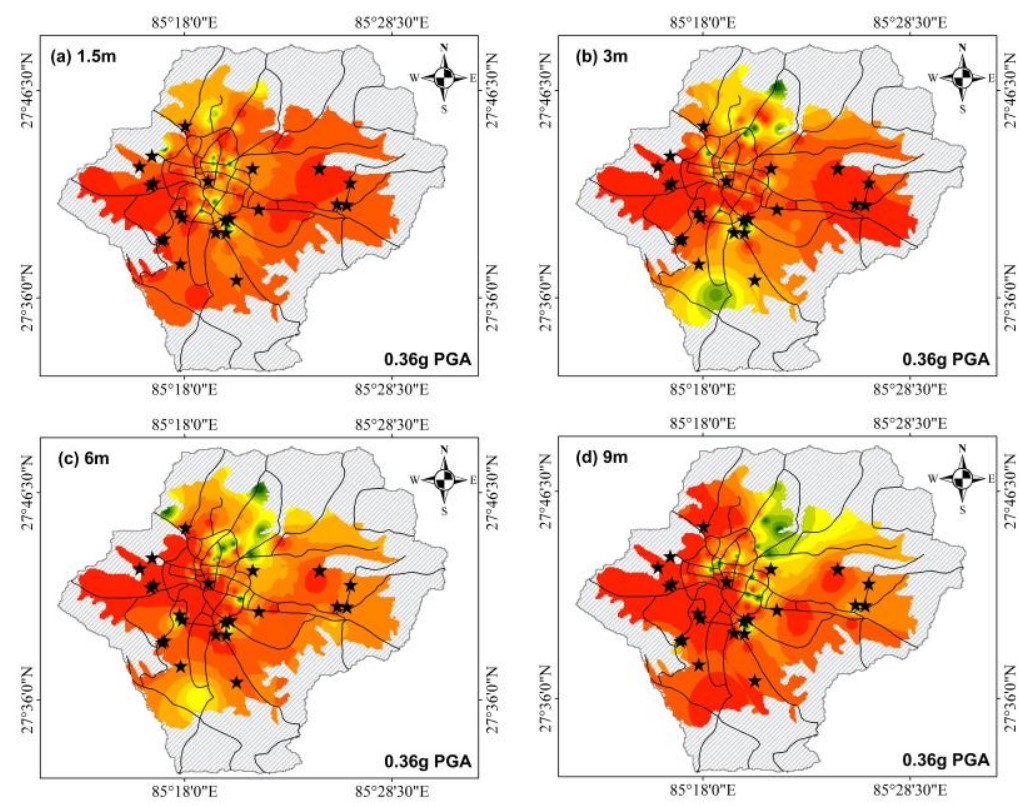

$\mathrm{PL}$

C 0.05

$0.05-0.1$

$0.1-0.2$

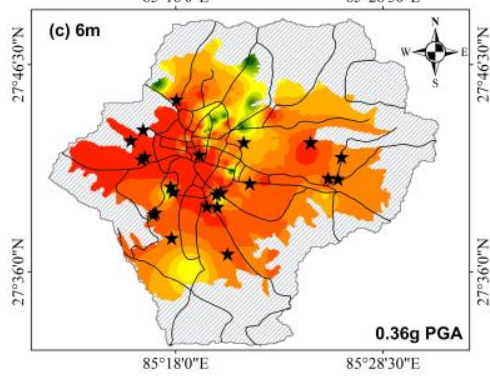

$0.2-0.3$

$\square 0.3-0.4$

$\square 0.4-0.5$

$\square 0.5-0.6$

$\square 0.6-0.7$

$0.7-0.8$

$0.8-0.9$

$0.9-1.0$

Bedrock
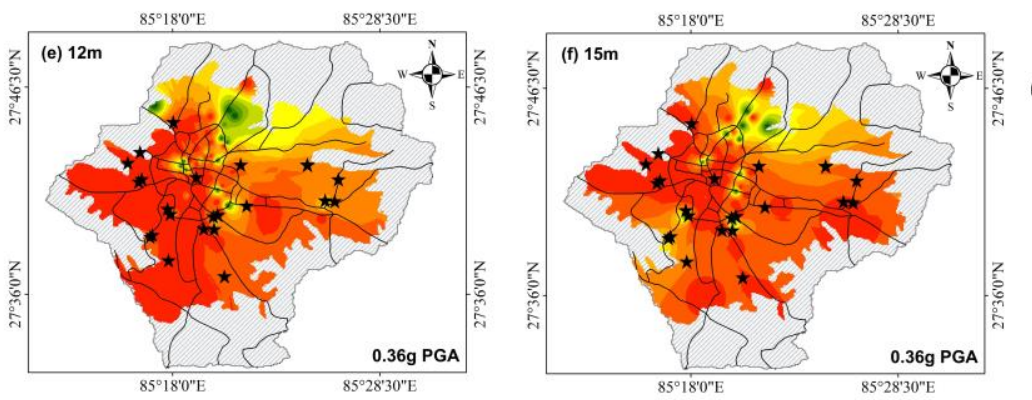

- Road Network

$\star 2015$ Eq. Liquefied Sites

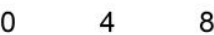

$16 \mathrm{Km}$

Figure 15. Maps showing the variation of $P_{\mathrm{L}}$ against liquefaction for $M_{\mathrm{w}} 8.4$ with $a_{\max }$ of $0.36 \mathrm{~g}$ at depths a) $1.5 \mathrm{~m}$, b) $3 \mathrm{~m}$, c) $6 \mathrm{~m}$, d) $9 \mathrm{~m}$, e) $12 \mathrm{~m}$, and f) $15 \mathrm{~m}$

The study's outcomes in terms of the $P_{\mathrm{L}}$ are presented in Figures 13-15. The maps were prepared using the in-built geostatical analysis tool of ArcGIS platform, considering Inverse Distance Weighted (IDW) interpolation. Variation of $P_{\mathrm{L}}$ for depths of $1.5 \mathrm{~m}, 3 \mathrm{~m}, 4.5 \mathrm{~m}, 6 \mathrm{~m}, 7.5 \mathrm{~m}, 9 \mathrm{~m}, 12 \mathrm{~m}$ and $15 \mathrm{~m}$ were interpolated for three earthquake scenarios. The greenish area represents a low liquefaction probability zone, and the reddish part shows a high probability of liquefaction zone. The authors observed that with an increase in earthquake magnitude and peak ground acceleration, the probability of liquefaction had significantly increased.

Furthermore, the probability of liquefaction has increased with increasing depth up to $9 \mathrm{~m}$, after which has geared down the value, as clearly shown in Figure 13. Similar is the case with the other two earthquake scenarios (Figure 14 and 15). In all maps in Figures 13-15, with some peripheries 
in western and eastern parts, it is observed that the central part of the valley is more susceptible to liquefaction. This result is validated with the past occurrence of liquefaction during the 1934 and 2015 earthquakes. Previous studies (Gautam et al., 2017; K. C. et al., 2020; Piya, 2004; Subedi et al., 2013) have also stated that the central region of Kathmandu valley is more susceptible to liquefaction than other parts.

Table 6 shows the range of $P_{\mathrm{L}}$ that validates the liquefaction susceptibility map obtained after the study by comparing it with the 2015 Gorkha earthquake-triggered liquefaction case studies inside Kathmandu Valley. Among 25 observed liquefied sites (as shown in Figure 13-15), 21 locations are found as highly liquefiable, and the remaining 4 locations are observed as very likely to liquefy using the hazard maps prepared by reliability based FOSM method.

Table 6. Validation of Kathmandu Valley liquefaction susceptibility map using the FOSM method by comparing with field observations of liquefaction during the 2015 Gorkha earthquake

\begin{tabular}{lccl}
\hline Location & Latitude & Longitude & $\boldsymbol{P}_{\mathbf{L}}$ \\
\hline Bagdol & $27.6676^{\circ} \mathrm{N}$ & $85.2980^{\circ} \mathrm{E}$ & $0.9-1.0$ \\
Bungamati & $27.6222^{\circ} \mathrm{N}$ & $85.2622^{\circ} \mathrm{E}$ & $0.9-1.0$ \\
& & & \\
Changunarayan, NEC & $27.709^{\circ} \mathrm{N}$ & $85.414^{\circ} \mathrm{E}$ & $0.8-0.9$ \\
& & & \\
Duwakot & $27.7094^{\circ} \mathrm{N}$ & $85.4139^{\circ} \mathrm{E}$ & $0.9-1.0$ \\
Guheshwori & $27.7093^{\circ} \mathrm{N}$ & $85.3576^{\circ} \mathrm{E}$ & $0.9-1.0$ \\
Gwarko & & & \\
& $27.6670^{\circ} \mathrm{N}$ & $85.338^{\circ} \mathrm{E}$ & $0.8-0.9$ \\
Harisiddhi & & & \\
Hattiban & $27.6549^{\circ} \mathrm{N}$ & $85.3352^{\circ} \mathrm{E}$ & $0.8-0.9$ \\
Imadol & $27.6668^{\circ} \mathrm{N}$ & $85.3344^{\circ} \mathrm{E}$ & $0.8-0.9$ \\
& $27.6668^{\circ} \mathrm{N}$ & $85.3383^{\circ} \mathrm{E}$ & $0.9-1.0$
\end{tabular}




\begin{tabular}{|c|c|c|c|}
\hline Itapakhe & $27.6792^{\circ} \mathrm{N}$ & $85.4289^{\circ} \mathrm{E}$ & $0.9-1.0$ \\
\hline Jharuwarashi & $27.6151^{\circ} \mathrm{N}$ & $85.3439^{\circ} \mathrm{E}$ & $0.7-0.8$ \\
\hline Kamalvinayak & $27.6785^{\circ} \mathrm{N}$ & $85.4370^{\circ} \mathrm{E}$ & $0.9-1.0$ \\
\hline Khadka Gaon & $27.6950^{\circ} \mathrm{N}$ & $85.2714^{\circ} \mathrm{E}$ & $0.9-1.0$ \\
\hline Lokanthali & $27.6748^{\circ} \mathrm{N}$ & $85.3626^{\circ} \mathrm{E}$ & $0.9-1.0$ \\
\hline Malpokhari & $27.6720^{\circ} \mathrm{N}$ & $85.2958^{\circ} \mathrm{E}$ & $0.9-1.0$ \\
\hline Manamaiju & $27.7453^{\circ} \mathrm{N}$ & $85.3007^{\circ} \mathrm{E}$ & $0.7-0.8$ \\
\hline Mulpani & $27.7025^{\circ} \mathrm{N}$ & $85.7005^{\circ} \mathrm{E}$ & $0.9-1.0$ \\
\hline Pakune Pati & $27.6969^{\circ} \mathrm{N}$ & $85.4401^{\circ} \mathrm{E}$ & $0.8-0.9$ \\
\hline Ramkot & $27.7110^{\circ} \mathrm{N}$ & $85.2622^{\circ} \mathrm{E}$ & $0.9-1.0$ \\
\hline Satdobato & $27.6552^{\circ} \mathrm{N}$ & $85.3264^{\circ} \mathrm{E}$ & $0.8-0.9$ \\
\hline Singhadurbar & $27.6987^{\circ} \mathrm{N}$ & $85.3200^{\circ} \mathrm{E}$ & $0.9-1.0$ \\
\hline Sitapaila & $27.7200^{\circ} \mathrm{N}$ & $85.2726^{\circ} \mathrm{E}$ & $0.8-0.9$ \\
\hline Syuchatar & $27.6972^{\circ} \mathrm{N}$ & $85.2740^{\circ} \mathrm{E}$ & $0.9-1.0$ \\
\hline Taudaha 1 & $27.6499^{\circ} \mathrm{N}$ & $85.2829^{\circ} \mathrm{E}$ & $0.7-0.8$ \\
\hline Taudaha 2 & $27.6484^{\circ} \mathrm{N}$ & $85.2811^{\circ} \mathrm{E}$ & $0.7-0.8$ \\
\hline
\end{tabular}

\section{CONCLUSIONS}

A reliability-based probabilistic approach was used to evaluate the liquefaction potential of Kathmandu valley. Probability of liquefaction was evaluated at different depths of 1510 boreholes from Kathmandu valley. The following are the main conclusions of this study: 
a) A significant higher probability of liquefaction can be observed even for factor of safety larger than one, depending on earthquake magnitude and peak ground acceleration. For example, a probability of liquefaction in the range of $0.43-0.45$ is observed even at a factor of safety of 1.2 for different earthquake scenario.

b) This fine-grained soil liquefaction susceptibility criteria shows that soil samples in the depth ranges of $0-5 \mathrm{~m}, 5-10 \mathrm{~m}$, and $10-15 \mathrm{~m}$ are more liquefiable than soil samples in depth ranges greater than $15 \mathrm{~m}$.

c) The central part of the Kathmandu valley is more susceptible to liquefaction than other parts.

d) The probability of liquefaction increases with increasing depth up to $9 \mathrm{~m}$, after which has geared down the value.

e) Based on probabilistic approach considering seismic and soil parameters uncertainties, probability of soil liquefaction calculated are in very good agreement with observed soil liquefaction during 2015 Gorkha earthquake.

f) The hazard maps prepared for different earthquake scenario can be useful for future infrastructure planning in Kathmandu Valley.

\section{DECLARATIONS}

\section{AVAILABILITY OF DATA AND MATERIALS}

The datasets used and/or analyzed during the current study are available from the corresponding author on reasonable request.

\section{COMPETING INTERESTS}

The authors declared no potential conflicts of interest with respect to the research, authorship, and/or publication of this article.

\section{FUNDING}

The authors received no specific funding for this research work.

\section{AUTHORS' CONTRIBUTIONS}

Conceptualization, MS and IPA; methodology, MS and IPA; software, MS; validation, MS and IPA; formal analysis, MS; investigation, MS; data curation, MS; writing - original draft 
preparation, MS; writing — review and editing, MS and IPA; supervision, IPA. All authors have read and agreed to the published version of the manuscript.

\section{ACKNOWLEDGEMENTS}

The first author sincere acknowledges the financial support received from Nepal Academy of Science and Technology (NAST) for the PhD Fellowship and the research guidance obtained through the Geo-Engineering and Geoscience Research Accelerator (GeoRA) program from BGC Engineering Inc. (Vancouver, Canada). The secondary borehole data and related information used in this work were obtained from various local organizations including Soil Test Pvt. Ltd., Pashupati Drillers, Multi Lab Pvt. Ltd., Clay Engineering, Archiplan Pvt. Ltd., Adarsha Design and Solutions Pvt. Ltd. We acknowledge the help received from Mr. Dipendra Gautam (CEO, Interdisciplinary Research Institute for Sustainability- IRIS) in acquiring deep borehole data. We also appreciate

the help of Mr. Rajan K.C. (Graduate Student, Institute of Engineering, Pulchowk Campus, Tribhuvan University) in preparing some of the maps used in this paper.

\section{REFERENCES}

Bolton Seed, H., Tokimatsu, K., Harder, L. F., \& Chung, R. M. (1985). Influence of SPT procedures in soil liquefaction resistance evaluations. Journal of Geotechnical Engineering, $111(12), 1425-1445$.

Boulanger, RW and Idriss, I. M. (2010). CPT and SPT Based Liquefaction Triggering Procedures. Center for Geotechnical Modeling, 10-02, 134.

Bray, J.D., \& Sancio, R.B. (2006). Assessment of the Liquefaction Susceptibility of FineGrained Soils. Journal of Geotechnical and Geoenvironmental Engineering, 132(9), 11651177. https://doi.org/10.1061/(ASCE)1090-0241(2006)132:9(1165)

Casagrande, A. (1947). Classification and Identification of Soils. Proceedings of the American Society of Civil Engineers, 73(6), 783-810.

Chen, C. J., \& Juang, C. H. (2000). Calibration of SPT-and CPT-based liquefaction evaluation methods. In Innovations and applications in geotechnical site characterization (pp. 49-64). 
Chen, Z. H., Burchfiel, B. C., Liu, Y., King, R. W., Royden, L. H., Tang, W., Wang, E., Zhao, J., \& Zhang, X. (2000). Global Positioning System measurements from eastern Tibet and their implications for India/Eurasia intercontinental deformation. Journal of Geophysical Research: Solid Earth, 105(B7), 16215-16227.

Choobbasti, A. J., Vafaei, A., \& Kutanaei, S. S. (2015). Mechanical properties of sandy soil improved with cement and nanosilica. Open Engineering, 1(open-issue).

Christian, J. T., \& Baecher, G. B. (2016). Sources of uncertainty in liquefaction triggering procedures. Georisk: Assessment and Management of Risk for Engineered Systems and Geohazards, 10(4), 242-250.

Dhital, M. (2015). Geology of the Nepal Himalaya: Regional perspective of the classic collided orogen. In Geology of the Nepal Himalaya: Regional Perspective of the Classic Collided Orogen. https://doi.org/10.1007/978-3-319-02496-7

Dixit, A. M., Yatabe, R., Dahal, R. K., \& Bhandary, N. P. (2013). Initiatives for earthquake disaster risk management in the Kathmandu Valley. Natural Hazards, 69(1), 631-654. https://doi.org/10.1007/s11069-013-0732-9

Duncan, J. M. (2000). Factors of safety and reliability in geotechnical engineering. Journal of Geotechnical and Geoenvironmental Engineering, 126(4), 307-316.

Gautam, D., de Magistris, F. S., \& Fabbrocino, G. (2017). Soil liquefaction in Kathmandu valley due to 25 April 2015 Gorkha, Nepal earthquake. Soil Dynamics and Earthquake Engineering, 97, 37-47.

Gilder, C. E. L., Pokhrel, R. M., \& Vardanega, P. J. (2019). The SAFER Borehole Database (SAFER/GEO-591_v1. 1). Bristol: University of Bristol. DOI, 10.

Holt, W. E., Chamot-Rooke, N., Le Pichon, X., Haines, A. J., Shen-Tu, B., \& Ren, J. (2000). Velocity field in Asia inferred from Quaternary fault slip rates and Global Positioning System observations. Journal of Geophysical Research: Solid Earth, 105(B8), 1918519209.

Hwang, J. H., Yang, C. W., \& Juang, D. S. (2004). A practical reliability-based method for 
assessing soil liquefaction potential. Soil Dynamics and Earthquake Engineering, 24(9-10), 761-770. https://doi.org/10.1016/j.soildyn.2004.06.008

Idriss, I M, \& Boulanger, R. W. (2010). SPT-based liquefaction triggering procedures. Rep. UCD/CGM-10, 2, 4-13.

Idriss, Izzat M, \& Boulanger, R. W. (2008). Soil liquefaction during earthquakes. Earthquake Engineering Research Institute.

Jha, S. K., Karki, B., \& Bhattarai, A. (2020). Deterministic and Probabilistic Evaluation of Liquefaction Potential: A Case Study from 2015 Gorkha (Nepal) Earthquake. Geotechnical and Geological Engineering, 38(4), 4369-4384. https://doi.org/10.1007/s10706-020-012777

Jha, S. K., \& Suzuki, K. (2009a). Reliability analysis of soil liquefaction based on standard penetration test. Computers and Geotechnics, 36(4), 589-596. https://doi.org/10.1016/j.compgeo.2008.10.004

Jha, S. K., \& Suzuki, K. (2009b). Liquefaction potential index considering parameter uncertainties. Engineering Geology 107, 55-60.

JICA. (2002). The study on earthquake disaster mitigation in the Kathmandu Valley, Kingdom of Nepal. In Japan International Cooperation Agency (JICA) and Ministry of Home Affairs (MOHA), Tokyo.

Jouanne, F., Mugnier, J.-L., Gamond, J. F., Le Fort, P., Pandey, M. R., Bollinger, L., Flouzat, M., \& Avouac, J. P. (2004). Current shortening across the Himalayas of Nepal. Geophysical Journal International, 157(1), 1-14.

K. C., S., Bhochhibhoya, S., Adhikari, P., Adhikari, P., \& Gautam, D. (2020). Probabilistic seismic liquefaction hazard assessment of Kathmandu valley, Nepal. Geomatics, Natural Hazards and Risk, 11(1), 259-271. https://doi.org/10.1080/19475705.2020.1718220

KMC. (2011). Kathmandu Metropolitan City.

Mugnier, J.-L., Huyghe, P., Gajurel, A. P., Upreti, B. N., \& Jouanne, F. (2011). Seismites in the 
Kathmandu basin and seismic hazard in central Himalaya. Tectonophysics, 509(1-2), 3349.

NBC, 105. (2020). Seismic design of buildings in Nepal.

Okamura, M., Bhandary, N. P., Mori, S., Marasini, N., \& Hazarika, H. (2015). Report on a reconnaissance survey of damage in Kathmandu caused by the 2015 Gorkha Nepal earthquake. Soils and Foundations, 55(5), 1015-1029. https://doi.org/10.1016/j.sandf.2015.09.005

Pathak, D. R., Hiratsuka, A., Awata, I., \& Chen, L. (2009). Groundwater vulnerability assessment in shallow aquifer of Kathmandu Valley using GIS-based DRASTIC model. Environmental Geology, 57(7), 1569-1578. https://doi.org/10.1007/s00254-008-1432-8

Paudyal, Y. R., Yatabe, R., Bhandary, N. P., \& Dahal, R. K. (2013). Basement topography of the Kathmandu Basin using microtremor observation. Journal of Asian Earth Sciences, 62, 627-637. https://doi.org/10.1016/j.jseaes.2012.11.011

Paul, J., Bürgmann, R., Gaur, V. K., Bilham, R., Larson, K. M., Ananda, M. B., Jade, S., Mukal, M., Anupama, T. S., \& Satyal, G. (2001). The motion and active deformation of India. Geophysical Research Letters, 28(4), 647-650.

Piya, B. K. (2004). Generation of a Geological database for the Liquefaction hazard assessment in Kathmandu valley. Geo-Information Science, March, 141.

Rajendran, C. P. (2021). Constraints on previous earthquakes from the liquefaction sites in the Kathmandu Valley associated with the 2015 Gorkha earthquake and their regional implications. Quaternary International, 585, 44-54.

https://doi.org/10.1016/j.quaint.2020.10.053

Sakai, H, Fujii, R., \& Kuwahara, Y. (2002). Changes in the depositional system of the PaleoKathmandu Lake caused by uplift of the Nepal Lesser Himalayas. Journal of Asian Earth Sciences, 20(3), 267-276.

Sakai, Harutaka. (2001). Stratigraphic division and sedimentary facies of the Kathmandu Basin Group, central Nepal. Journal of Nepal Geological Society, 25(Sp. Issue), 19-32. 
Seed, H Bolton, Idriss, I. M., \& Arango, I. (1983). Evaluation of liquefaction potential using field performance data. Journal of Geotechnical Engineering, 109(3), 458-482.

Seed, Harry Bolton, \& Idriss, I. M. (1971). Simplified procedure for evaluating soil liquefaction potential. Journal of Soil Mechanics \& Foundations Div.

Seed, R. B., Cetin, K. O., \& Moss, R. E. S. (2001). Recent advances in soil liquefaction engineering and seismic site response evaluation. Fourth International Conference on Recent Advances in Geotechnical Earthquake Engineering and Soil Dynamics and Symposium in Honor of Professor W.D. Liam Finn, 1-45.

Sella, G. F., Dixon, T. H., \& Mao, A. (2002). REVEL: A model for recent plate velocities from space geodesy. Journal of Geophysical Research: Solid Earth, 107(B4), ETG-11.

Sharma, K., Deng, L., \& Khadka, D. (2019). Reconnaissance of liquefaction case studies in 2015 Gorkha (Nepal) earthquake and assessment of liquefaction susceptibility. International Journal of Geotechnical Engineering, 13(4), 326-338. https://doi.org/10.1080/19386362.2017.1350338

Sharma, K., Deng, L., \& Noguez, C. C. (2016). Field investigation on the performance of building structures during the April 25, 2015, Gorkha earthquake in Nepal. Engineering Structures, 121, 61-74. https://doi.org/10.1016/j.engstruct.2016.04.043

Sharma, K., Subedi, M., Acharya, I., \& Pokharel, B. (2018). Geotechnical and Structural Aspect of 2015 Gorkha Nepal Earthquake and Lesson Learnt. Journal of the Institute of Engineering, 13(1 SE-Articles). https://doi.org/10.3126/jie.v13i1.20345

Shrestha, S., Semkuyu, D. J., \& Pandey, V. P. (2016). Assessment of groundwater vulnerability and risk to pollution in Kathmandu Valley, Nepal. Science of the Total Environment, 556, 23-35. https://doi.org/10.1016/j.scitotenv.2016.03.021

Singnar, L., \& Sil, A. (2018). Liquefaction potential assessment of Guwahati city using firstorder second-moment method. Innovative Infrastructure Solutions, 3(1). https://doi.org/10.1007/s41062-018-0138-3

Subedi, M, Sharma, K., Upadhayay, B., Poudel, R. K., \& Khadka, P. (2013). Soil liquefaction 
potential in Kathmandu Valley. International Journal of Landslide and Environment, 1(1), 91-92.

Subedi, Mandip, Sharma, K., Acharya, I. P., \& Adhikari, K. (2018). Soil liquefaction in Kathmandu Valley due to 2015 Gorkha, Nepal Earthquake and assessment of liquefaction susceptibility.

Thapa, D. R., Tao, X., Wang, G., \& Fan, F. (2017). Deterministic seismic hazard assessment for Nepal. 16th World Conference on Earthquake Engineering (16WCEE-2017, Paper No. 730), Santiago, Chile.

Tsuchida, H., \& Hayashi, S. (1972). Estimation of liquefaction potential of sandy soils. Publication of: Mcgraw Hill Book Company, 14.

UNDP/HMG/UNCHS. (1994). Seismic hazard Mapping and Risk Assessment for Nepal.

Wang, Q., Zhang, P.-Z., Freymueller, J. T., Bilham, R., Larson, K. M., You, X., Niu, Z., Wu, J., Li, Y., \& Liu, J. (2001). Present-day crustal deformation in China constrained by global positioning system measurements. Science, 294(5542), 574-577.

Youd, T. L., \& Idriss, I. M. (2001). Liquefaction resistance of soils: summary report from the 1996 NCEER and 1998 NCEER/NSF workshops on evaluation of liquefaction resistance of soils. Journal of Geotechnical and Geoenvironmental Engineering, 127(4), 297-313. 